\title{
Paralia (Bacillariophyta) stowaways in ship ballast: implications for biogeography and diversity of the genus
}

\author{
Michael L MacGillivary ${ }^{\dagger}$ and Irena Kaczmarska ${ }^{*+}$
}

\begin{abstract}
Background: The genus Paralia Heiberg is one of the most recognizable, widely distributed and commonly reported diatoms from contemporary coastal marine environments and ship ballast. Species discovery has historically been made in diatoms through the recognition of morphological discontinuities between specimens, first using light and later electron microscopy. However, recently, morphologically semi-cryptic species of Paralia were delineated using genetic analyses, among mostly tropical and subtropical sites.

Results: Ten morphological characters of the frustules and sequence fragments from the nuclear genome (conserved $18 \mathrm{~S}$ regions of ribosomal RNA and the variable internal transcribed spacer [ITS]), and from the RuBisCo large subunit $(r b c L)$ gene of the chloroplast genome were examined. Frustule morphology did not segregate species, however, comparisons of sequence fragments and ITS2 secondary structures yielded a new species from North American waters, P. guyana (with four genodemes), and another widely-distributed species, P. marina. The latter was lecto- and epitypified here because it is most similar to specimens in the type preparation BM1021 representing Smith's concept of the species. Paralia marina and certain genodemes of $P$. guyana were morphologically cryptic. Only those genodemes of $P$. guyana that possess prickly separation valves could be morphologically distinguished from P. marina with relative confidence in SEM preparations. All clones established from chains isolated from the ballast sediment of the ships sailing along the Atlantic coast of North America belonged to P. guyana. All DNA sequences of preserved Paralia chains recovered from the three trans-Atlantic voyages (TAVs) samples arriving to eastern Canada from Europe shared $100 \%$ identity with P. marina.

Conclusion: First, if the $\bar{x}=130592$ P. marina cells per ballast tank at the end of the TAVs represents their abundance in ballast tanks of similar crossings and following mid-ocean ballast water exchange, then this diatom, if de-ballasted, exerts a strong and continued propagule pressure on Eastern Canadian coasts. Despite this, as of 2009, P. marina was found only in Cheticamp, Nova Scotia, Canada. Second, genetic analysis readily segregated cryptic and semi-cryptic taxa of Paralia, highlighting the usefulness of the molecular approach to species recognition, e.g., in programs monitoring alien introductions.
\end{abstract}

Keywords: Diatoms, Lectotype, Epitype, Molecular taxonomy, Paralia species complex, Cryptic diversity, ITS2 secondary structure, Ship ballast

\footnotetext{
* Correspondence: iehrman@mta.ca

${ }^{\dagger}$ Equal contributors

Department of Biology, Mount Allison University, 63B York Street, Sackville, NB E4L 1G7, Canada
} 


\section{Background}

Evaluation of several cosmopolitan, eurytopic or taxonomically challenging diatom species from a wide spectrum of genera with a combination of comprehensive morphometric and molecular analyses has consistently led to the discovery of a number of new cryptic and semi-cryptic following [1,2] species e.g., [3-8]. However, these are a minute fraction of the 100000 or more extant diatom species [9]. Thus the application of systematic analysis using both morphometric and molecular approaches to previously less-explored taxa would likely result in the discovery of more new species.

The commonly reported, easily-recognisable, centric diatom Paralia sulcata (hereafter referred to as $P$. sulcata sensu lato [broadly defined or s.l.] to indicate reports published before P. sulcata sensu stricto [strictly defined or $s$. s.] was lectotypified [10]) is known worldwide from coastal marine waters and contemporary and fossil sediments. Such records may reflect a truly cosmopolitan nature of the species, but may also be an artefact of relying solely on Light Microscopy (LM) for species identification. LM is insufficient to resolve all diagnostic characters necessary to identify some of the species of Paralia [6,10-13]. For example, the use of Scanning Electron Microscopy (SEM) revealed a number of new Paralia species including: $P$. elliptica Garcia [14], P. fenestrata Sawai and Nagumo and P. capitata Sawai and Nagumo [12], P. longispina Konno and Jordan [13] and P. ehrmanii MacGillivary [6]. Two additional new species, $P$. allisonii MacGillivary and $P$. crawfordii MacGillivary, were delineated using both morphological and molecular characters [6]; the first two such cases in the genus. Nonetheless, the studies above do not represent a global survey of Paralia populations and the global species richness of this genus is not yet fully known.

More than one entity conforming to a historically practiced broad diagnosis of Paralia sulcata [15] has recently been discovered [10]. However, fossilised specimens of Paralia Heiberg from Ehrenberg's original collection have since become available for SEM examination. This original gathering revealed the existence of two morphologically discrete taxa; $P$. sulcata (corresponding to Ehrenberg's description [16]) and a new species, P. obscura MacGillivary. The latter is morphologically similar to P. sulcata (sensu [15]). Crawford [15] inferred that the Plymouth specimens of Paralia corresponded to Ehrenberg's P. sulcata and were the same (pg. 209 of [15] as far as it could have been determined at that time) as those present on Smith's BM1021 preparation (designated as the generitype slide of Paralia [15] labelled Orthosira marina [17]). Consequently, a better understanding of Smith's [17] concept of O. marina, later transferred by Heiberg [18] to Paralia ( $P$. marina (Smith) Heiberg), may render circumscription of this species more precisely and therefore better clarify its affiliation to Ehrenberg's $P$. sulcata, about which Smith himself was somewhat unclear (pg. 60 in [17]).

Paralia sulcata s.l. is also one of the most common diatom-stowaways in ships' ballast tanks [19-25]. Ship ballast is an important human-mediated transport vector for the unintentional introduction of non-native, potentially invasive species to new regions e.g., [19,26-28] and has been held responsible for the establishment of diatoms outside their native range, such as, Coscinodiscus wailesii Gran \& Angst [29], Odontella sinensis (Greville) Grunow [30] or Thalassiosira punctigera (Castracane) Hasle [31].

The potential for non-native species introductions has grown in the past 50 years due to an increase in both the volume of ballast water carried by individual commercial vessels and the magnitude of international trade e.g., [26,32,33]. These developments have led international ports and their neighbourhoods to incur an overall higher propagule pressure of alien organisms which is, in part, a function of the number of individuals introduced and the rate at which they arrive [34-36]. Consequently, the number of ballast water mediated introductions of non-indigenous and even invasive species has continued to grow $[37,38]$. These introductions may remain underestimated for smaller organisms due to insufficient knowledge of native, regional florae that have not been systematically examined before industrial communities began to change their coastal environments. This is particularly true for microscopic organisms, including diatoms, where application of molecular means of species recognition [39-43] has demonstrated the presence of semi-cryptic or cryptic taxa, some of which survive in ship ballasts with days-long transport out of their native range [44].

The aims of this study were three-fold. First morphological (SEM-based) and molecular tools (18S, $r b c \mathrm{~L}$ and ITS DNA sequences) were used to characterise 76 clones of Paralia isolated from the coastal waters of Canada, live sediments collected from ballast tanks of intercoastal ships docked at the ports of Saint John, New Brunswick and Halifax, Nova Scotia, and from a number of sites worldwide. Second, these results were compared to ITS DNA data recovered from the single-chain amplification of ethanol-fixed Paralia cells collected from ballast tank water in three trans-Atlantic vessels arriving to eastern Canadian ports from Europe to evaluate the potential for transport of European Paralia to Canada. Finally, specimens of Paralia from the preparation BM1021 were examined using LM in order to better understand Smith's [17] concept of P. marina (as Orthosira marina) and to relate it to our clones. 


\section{Results}

\section{Species identity}

In total, 76 clonal isolates and 18 chains of Paralia (approximately 2000 valves altogether) were investigated from natural sediment and plankton samples worldwide and from ship ballast sediments and waters arriving at Atlantic Canadian ports (TAVs; Table 1). Consequently, two species were recovered; a previously described, but broadly delineated entity, Paralia marina, lectotypified here, and a species new to science, $P$. guyana, represented by four genodemes. These taxa were all morphologically semi-cryptic or cryptic (Figures 1, 2, 3, 4, 5, 6, 7 , and 8) and were most reliably delineated based on DNA sequence data analyses.

Paralia marina (W. Smith) Heiberg (Figures 2A-H; 3A-H; 4A-D; Table 2).

Lectotype (designated here). Drawing of sibling valves from Smith ([17], pl. 53, figure 338); labelled as '7' on Figure $2 \mathrm{~A}$. The valve noted above most closely represents those found on Smith's preparation currently at the British Museum BM1021; no specimen was marked on this preparation.

Lectotype locality. Kinsale Harbour, Ireland (indicated on preparation BM1021 as such). Smith's [17] diagnosis reads 'Filaments direct; cell-cavity sub-spherical; valve with large irregular cellules, and a deep submedian sulcus or depression; junction-surfaces striated; striae radiating. Breadth of filament $\bullet 0006$ " to $\bullet 0018$ ". v.v.' The $\cdot 0006$ " to $\bullet 0018$ " v.v. given in the original description corresponds to $15.2-45.7 \mu \mathrm{m}$ valve diameter in units used in modern diatom taxonomy.

Epitype (designated here). SEM preparation B40 0040792 from strain 1059/2 (labelled as Paralia sulcata) from the Culture Collection of Algae and Protozoa (CCAP), deposited at The Botanic Gardens and Botanical Museum (BGBM) in Berlin-Dahlem, Berlin, Germany. The entire ITS region and sequence fragments of the $r b c \mathrm{~L}$ and 18S rRNA genes and voucher specimens are deposited in GenBank via the Barcoding of Life Data (BOLD) System (accession numbers in Table 1).

Epitype locality: Isolated from Loch Creran, Argyll, Scotland $\left(56^{\circ} 32^{\prime} \mathrm{N}, 05^{\circ} 20^{\prime} \mathrm{W}\right)$ as given at CCAP for CCAP 1059/2.

Rationale for lecto- and epitypification: As was common practice at the time, Smith did not establish the holotype for Orthosira marina (transferred to Paralia by Heiberg [18]). The Botanical Code [45], and Jahn \& Kusber [46] in the context of diatoms, state that: 'a specimen from its original material such as pictures, isotypes (duplicates) or syntypes' may be used as a lectotype when no holotype has been designated (as is the case here), providing the material was in the hands of the describer at the time of description. Crawford [15] has noted that 'Since Heiberg stated definitively that the type of Paralia is Orthosira marina W. Smith the British Museum slide, number 1021, must be regarded as a lectotype of Paralia'. Because Smith's BM1021 preparation contains no marked specimen, one of Smith's [17] drawings (pl. 53, figure 338, marked as 7 here; cells sizes not given) was designated as the lectotype for P. marina. However, figure 338 [17] seems to show two morphotypes. This might have contributed to ambiguities surrounding the status of this species and its relationship to the earlier described P. sulcata. Indeed, drawings labelled 5, 6 and 8-10 here (Figure 2A) have the characteristic wide, open fenestrae of Miocene $P$. sulcata s.s. and extant P. fenestrata (compare to figure 33 of [10]). The drawings labelled 1-4 and 7 here (Figure 2A), on the other hand, have narrow fenestrae that are more characteristic of those seen in the Paralia valves on preparation BM1021 (Figure 2B-I, figures seven to nine in [15]); no unmounted material examined by Smith was available to the authors.

Although two contemporary species, $P$. marina and $P$. guyana (described below), share many characters of the intercalary frustule morphology discernible in LM and are comparable to LM images of Smith's BM1021 preparation (Figure 2B-I), the epitype of $P$. marina was chosen from the clone established from Loch Creran, Scotland (CCAP 1059/2). The site, approximately $500 \mathrm{~km}$ away, was the one nearest to where the sample for preparation BM1021 was obtained, Kinsale Harbour, Ireland; although there is no guarantee that the Paralia sampled by W. Smith in the mid-1800s still exists at this site.

Emended description: Valves circular and heavilysilicified. Separation valve face (shown to carry the best discriminating characters in this and other studies) is devoid of prickles or marginal spines. On intercalary valves, long, slender, capitate marginal linking spines interdigitate with notches between the square-shouldered, short and blunt spines (sensu [12]) in sibling valves to form filamentous colonies. Fenestrae, two areolae wide, are bordered by siliceous outgrowths and occur on the valve mantle. They are obscured by a siliceous covering in fully silicified valves when observed in SEM. Internally, the mantle rim is smooth. Just below the overhanging mantle edge are irregularly spaced rimoportulae which, when present, replace a few pore areolae in striae that otherwise run the length of the mantle. Nuclear rDNA ITS2 secondary structure of this diatom has five helices, a $\mathrm{C}: \mathrm{U}$ mismatch in Helix II and a UGGU super-conserved motif on the $5^{\prime}$ side of Helix III (compare to [6], figure 45, ellipse).

Morphometrics of valves on preparation BM1021: Overall, 97 valves were examined and the following characters were measured: valve diameter $(\mathrm{n}=97 ; \bar{x}=$ $16.6 \mu \mathrm{m}$; range $=10.8-33.2 \mu \mathrm{m})$, the number of fenestrae $(\mathrm{n}=19 ; \bar{x}=15.6$ in $10 \mu \mathrm{m}$; range $=12.4-17.9$ in $10 \mu \mathrm{m})$, 
Table 1 Identities, sources and isolation dates of Paralia clones

\begin{tabular}{|c|c|c|c|c|c|c|}
\hline \multirow[t]{2}{*}{ Clone identifier } & \multirow[t]{2}{*}{ Site } & \multirow[t]{2}{*}{ Origin } & \multirow[t]{2}{*}{ Isolated } & \multicolumn{3}{|c|}{ GenBank accession numbers } \\
\hline & & & & ITS & $18 \mathrm{~S}$ & $r b c \mathrm{~L}$ \\
\hline \multicolumn{7}{|l|}{ P. marina } \\
\hline AC554 & Baie des Veys, FR & $49^{\circ} 23^{\prime} \mathrm{N}, 001^{\circ} 07^{\prime} \mathrm{W}$ & 2002 & KP150159 & KP150015 & KP150087 \\
\hline CAWB38 & Croisilles Harbour, NZ & $41^{\circ} 03^{\prime} \mathrm{S}, 173^{\circ} 39^{\prime} \mathrm{E}$ & 01/01/98 & KP150160 & KP150016 & KP150088 \\
\hline CCAP $1059 / 1^{1}$ & Lynn of Lorn, UK & $56^{\circ} 30^{\prime} \mathrm{N}, 005^{\circ} 28^{\prime} \mathrm{W}$ & $01 / 12 / 02$ & KP150150 & KP150008 & KP150080 \\
\hline CCAP1059/2 1 & Loch Creran, UK & $56^{\circ} 32^{\prime} \mathrm{N}, 005^{\circ} 20^{\prime} \mathrm{W}$ & 2005 & KP150152 & KP150010 & KP150082 \\
\hline Chet1 & Cheticamp, CA & $46^{\circ} 37^{\prime} \mathrm{N}, 061^{\circ} 00^{\prime} \mathrm{W}$ & 13/08/09 & KP150158 & KP150014 & KP150086 \\
\hline Helgo $1^{1,2}$ & Helgoland, DE & $54^{\circ} 10^{\prime} \mathrm{N}, 007^{\circ} 53^{\prime} \mathrm{E}$ & 20/02/07 & KP150153 & KP150011 & KP150083 \\
\hline Helgo $2^{1,2}$ & $"$ & $"$ & 06/03/07 & KP150155 & KP150012 & KP150084 \\
\hline Helgo3 $3^{1,2}$ & $"$ & $"$ & 03/07/07 & KP150149 & KP150007 & KP150079 \\
\hline Helgo $4^{1,2}$ & $"$ & $"$ & 06/12/07 & KP150147 & KP150005 & KP150077 \\
\hline $\operatorname{Par1}^{1,3}$ & Trieste, IT & $45^{\circ} 42^{\prime} \mathrm{N}, 013^{\circ} 42^{\prime} \mathrm{E}$ & 04/28/06 & KP150143 & N/A & KP150074 \\
\hline $\operatorname{Par} 2^{1,3}$ & $"$ & $"$ & 04/28/06 & KP150144 & N/A & KP150075 \\
\hline TAV1 & Multiple & Multiple & Multiple & KP150156 & N/A & N/A \\
\hline TAV2 & $"$ & $"$ & $"$ & KP150146 & $\mathrm{N} / \mathrm{A}$ & N/A \\
\hline TAV3 & $"$ & $"$ & $"$ & KP150154 & N/A & N/A \\
\hline Uru1 & Montevideo, UY & $34^{\circ} 57^{\prime} \mathrm{S}, 056^{\circ} 09^{\prime} \mathrm{W}$ & $31 / 07 / 09$ & KP150145 & KP150004 & KP150076 \\
\hline Uru2 & $"$ & $"$ & $31 / 07 / 09$ & KP150148 & KP150006 & KP150078 \\
\hline Uru3 & $"$ & $"$ & $31 / 07 / 09$ & KP150157 & KP150013 & KP150085 \\
\hline Uru6 & $"$ & $"$ & $31 / 07 / 09$ & KP150151 & KP150009 & KP150081 \\
\hline \multicolumn{7}{|c|}{ P. guyana 'smooth' genodeme } \\
\hline EC102-5 & Sydney, CA & $46^{\circ} 08^{\prime} \mathrm{N}, 060^{\circ} 11^{\prime} \mathrm{W}$ & 15/07/09 & N/A & KP149985 & KP150057 \\
\hline EC105-2 & Portland, US & $43^{\circ} 39^{\prime} \mathrm{N}, 070^{\circ} 15^{\prime} \mathrm{W}$ & 03/08/09 & KP150127 & KP149986 & KP150058 \\
\hline EC106-1 & Boston, US & $42^{\circ} 21^{\prime} \mathrm{N}, 071^{\circ} 03^{\prime} \mathrm{W}$ & 07/08/09 & $\mathrm{N} / \mathrm{A}$ & KP149964 & KP150036 \\
\hline EC107-3 & $"$ & $"$ & 07/08/09 & KP150113 & KP149972 & KP150044 \\
\hline EC108-1 & Belledune, CA & $47^{\circ} 51^{\prime} \mathrm{N}, 065^{\circ} 51^{\prime} \mathrm{W}$ & 07/08/09 & KP150129 & KP149988 & KP150060 \\
\hline EC109-2 & Botwood, CA & $49^{\circ} 08^{\prime} \mathrm{N}, 055^{\circ} 21^{\prime} \mathrm{W}$ & 07/08/09 & KP150108 & KP149966 & KP150038 \\
\hline EC110-2 & Stephenville, CA & $48^{\circ} 33^{\prime} \mathrm{N}, 058^{\circ} 33^{\prime} \mathrm{W}$ & 07/08/09 & KP150124 & KP149983 & KP150055 \\
\hline EC111-1 & Portland, US & $43^{\circ} 39^{\prime} \mathrm{N}, 070^{\circ} 15^{\prime} \mathrm{W}$ & 11/08/09 & KP150115 & KP149974 & KP150046 \\
\hline EC112-3 & Boston, US & $42^{\circ} 21^{\prime} \mathrm{N}, 071^{\circ} 03^{\prime} \mathrm{W}$ & 11/08/09 & KP150122 & KP149981 & KP150053 \\
\hline EC113-3 & Charlottetown, CA & $46^{\circ} 14^{\prime} \mathrm{N}, 063^{\circ} 07^{\prime} \mathrm{W}$ & 11/08/09 & KP150111 & KP149970 & KP150042 \\
\hline EC114-2 & St. John's, CA & $47^{\circ} 33^{\prime} \mathrm{N}, 052^{\circ} 42^{\prime} \mathrm{W}$ & 11/08/09 & KP150132 & KP149991 & KP150063 \\
\hline EC115-1 & Boston, US & $42^{\circ} 21^{\prime} \mathrm{N}, 071^{\circ} 03^{\prime} \mathrm{W}$ & 13/08/09 & KP150123 & KP149982 & KP150054 \\
\hline EC116-4 & Bucksport, US & $44^{\circ} 34^{\prime} \mathrm{N}, 068^{\circ} 47^{\prime} \mathrm{W}$ & 13/08/09 & KP150136 & KP149995 & KP150067 \\
\hline EC117-1 & Corner Brook, CA & $48^{\circ} 57^{\prime} \mathrm{N}, 057^{\circ} 57^{\prime} \mathrm{W}$ & 27/08/09 & KP150105 & KP149962 & KP150034 \\
\hline EC118-1 & Sydney, CA & $46^{\circ} 08^{\prime} \mathrm{N}, 060^{\circ} 11^{\prime} \mathrm{W}$ & 27/08/09 & KP150116 & KP149975 & KP150047 \\
\hline $\mathrm{BH} 2$ & Bar Harbour, US & $44^{\circ} 23^{\prime} \mathrm{N}, 068^{\circ} 12^{\prime} \mathrm{W}$ & 12/08/09 & KP150106 & KP149963 & KP150035 \\
\hline CB5 & Chaleur Bay, CA & $47^{\circ} 59^{\prime} \mathrm{N}, 066^{\circ} 40^{\prime} \mathrm{W}$ & 03/07/09 & KP150139 & KP149998 & KP150070 \\
\hline $\mathrm{CT} 2$ & Cape Tormentine, CA & $46^{\circ} 07^{\prime} \mathrm{N}, 063^{\circ} 47^{\prime} \mathrm{W}$ & 03/07/09 & KP150138 & KP149997 & KP150069 \\
\hline GA3 & Grande Anse, CA & $49^{\circ} 04^{\prime} \mathrm{N}, 068^{\circ} 24^{\prime} \mathrm{W}$ & 06/06/09 & KP150128 & KP149987 & KP150059 \\
\hline IngoB3 & Ingonish, CA & $46^{\circ} 42^{\prime} \mathrm{N}, 060^{\circ} 22^{\prime} \mathrm{W}$ & 05/10/09 & KP150134 & KP149993 & KP150065 \\
\hline Ingram & Ingramsport, CA & $44^{\circ} 39^{\prime} \mathrm{N}, 063^{\circ} 58^{\prime} \mathrm{W}$ & 25/10/09 & KP150119 & KP149978 & KP150050 \\
\hline
\end{tabular}


Table 1 Identities, sources and isolation dates of Paralia clones (Continued)

\begin{tabular}{|c|c|c|c|c|c|c|}
\hline Mait1 & Maitland Beach, CA & $43^{\circ} 59^{\prime} \mathrm{N}, 066^{\circ} 09^{\prime} \mathrm{W}$ & 08/09/09 & KP150135 & KP149994 & KP150066 \\
\hline MB2 & Maces Bay, CA & $45^{\circ} 05^{\prime} \mathrm{N}, 066^{\circ} 28^{\prime} \mathrm{W}$ & 14/08/09 & KP150120 & KP149979 & KP150051 \\
\hline Min2 & Minudie, CA & $45^{\circ} 46^{\prime} \mathrm{N}, 064^{\circ} 21^{\prime} \mathrm{W}$ & 03/07/09 & KP150130 & KP149989 & KP150061 \\
\hline Moose3 & Moose Cove, CA & $45^{\circ} 37^{\prime} \mathrm{N}, 064^{\circ} 31^{\prime} \mathrm{W}$ & 07/07/09 & N/A & KP149969 & KP150041 \\
\hline MP1 & Mary's Point, CA & $45^{\circ} 41^{\prime} \mathrm{N}, 064^{\circ} 34^{\prime} \mathrm{W}$ & 07/07/09 & KP150133 & KP149992 & KP150064 \\
\hline NMB1 & Noel, CA & $45^{\circ} 17^{\prime} \mathrm{N}, 063^{\circ} 44^{\prime} \mathrm{W}$ & 08/09/09 & KP150118 & KP149977 & KP150049 \\
\hline PM3 & Pretty Marsh, ME & $44^{\circ} 20^{\prime} \mathrm{N}, 068^{\circ} 23^{\prime} \mathrm{W}$ & 12/08/09 & KP150110 & KP149968 & KP150040 \\
\hline Que 53-1 & Baie aux Outardes, CA & $49^{\circ} 04^{\prime} \mathrm{N}, 068^{\circ} 24^{\prime} \mathrm{W}$ & 10/10/09 & KP150112 & KP149971 & KP150043 \\
\hline SV7 & Shediac Valley, CA & $47^{\circ} 20^{\prime} \mathrm{N}, 064^{\circ} 25^{\prime} \mathrm{W}$ & 03/03/09 & KP150131 & KP149990 & KP150062 \\
\hline SV8 & $"$ & $"$ & 03/03/09 & KP150137 & KP149996 & KP150068 \\
\hline SV9 & $"$ & $"$ & 03/03/09 & KP150117 & KP149976 & KP150048 \\
\hline SV12 & $"$ & $"$ & 03/03/09 & KP150126 & N/A & N/A \\
\hline SV14 & $"$ & $"$ & 03/03/09 & KP150142 & KP150001 & KP150073 \\
\hline $\operatorname{Van} 2 \mathrm{~A} 1$ & Ucluelet Peninsula, CA & $48^{\circ} 55^{\prime} \mathrm{N}, 125^{\circ} 32^{\prime} \mathrm{W}$ & 19/05/10 & KP150140 & KP149999 & KP150071 \\
\hline Van4B3 & Tofino, CA & $49^{\circ} 09^{\prime} \mathrm{N}, 125^{\circ} 53^{\prime} \mathrm{W}$ & $19 / 05 / 10$ & KP150114 & KP149973 & KP150045 \\
\hline $\operatorname{Van} 5 \mathrm{~A} 1$ & Tsawwassen, CA & $49^{\circ} 01^{\prime} \mathrm{N}, 123^{\circ} 06^{\prime} \mathrm{W}$ & 19/05/10 & KP150109 & KP149967 & KP150039 \\
\hline $\operatorname{Van} 5 \mathrm{~A} 2$ & $"$ & $"$ & $19 / 05 / 10$ & KP150141 & KP150000 & KP150072 \\
\hline W5 & Windsor, CA & $44^{\circ} 59^{\prime} \mathrm{N}, 068^{\circ} 08^{\prime} \mathrm{W}$ & 28/05/09 & KP150121 & KP149980 & KP150052 \\
\hline YCB4 & North Sydney, CA & $46^{\circ} 12^{\prime} \mathrm{N}, 060^{\circ} 15^{\prime} \mathrm{W}$ & 03/10/09 & KP150107 & KP149965 & KP150037 \\
\hline YH1 & Yarmouth, CA & $43^{\circ} 50^{\prime} \mathrm{N}, 066^{\circ} 06^{\prime} \mathrm{W}$ & 08/09/09 & KP150125 & KP149984 & KP150056 \\
\hline \multicolumn{7}{|c|}{ P. guyana 'caisn' genodeme } \\
\hline VanA4 & Nanaimo, CA & $49^{\circ} 12^{\prime} \mathrm{N}, 123^{\circ} 57^{\prime} \mathrm{W}$ & $31 / 01 / 10$ & KP150089 & KP149947 & KP150018 \\
\hline $\operatorname{Van} 2 B 2$ & Ucluelet Peninsula, CA & $48^{\circ} 55^{\prime} \mathrm{N}, 125^{\circ} 32^{\prime} \mathrm{W}$ & $19 / 05 / 10$ & KP150091 & KP149949 & KP150020 \\
\hline $\operatorname{Van} 4 \mathrm{~A} 2$ & Tofino, CA & $49^{\circ} 09^{\prime} \mathrm{N}, 125^{\circ} 53^{\prime} \mathrm{W}$ & $19 / 05 / 10$ & KP150094 & KP149952 & KP150023 \\
\hline $\operatorname{Van} 4 \mathrm{C1}$ & $"$ & $"$ & 19/05/10 & KP150093 & KP149951 & KP150022 \\
\hline West11B4 & Marshall, US & $38^{\circ} 09^{\prime} \mathrm{N}, 122^{\circ} 53^{\prime} \mathrm{W}$ & $27 / 05 / 10$ & KP150095 & KP149953 & KP150024 \\
\hline West11C2 & $"$ & $"$ & $27 / 05 / 10$ & KP150092 & KP149950 & KP150021 \\
\hline West11C3 & $"$ & $"$ & $27 / 05 / 10$ & KP150090 & KP149948 & KP150019 \\
\hline \multicolumn{7}{|c|}{ P. guyana 'capebreton' genodeme } \\
\hline GP1 & Grove's Point, CA & $46^{\circ} 13^{\prime} \mathrm{N}, 060^{\circ} 20^{\prime} \mathrm{W}$ & 12/08/09 & KP150096 & KP149954 & KP150025 \\
\hline GP2 & $"$ & $"$ & 12/08/09 & KP150098 & KP149956 & KP150027 \\
\hline GP3 & $"$ & $"$ & $12 / 08 / 09$ & KP150099 & KP149957 & KP150028 \\
\hline GP4 & $"$ & $"$ & 12/08/09 & KP150097 & KP149955 & KP150026 \\
\hline GP5 & $"$ & $"$ & $12 / 08 / 09$ & KP150101 & KP149959 & KP150030 \\
\hline GP6 & $"$ & $"$ & $12 / 08 / 09$ & KP150100 & KP149958 & KP150029 \\
\hline \multicolumn{7}{|c|}{ P. guyana 'servidei' genodeme } \\
\hline $\operatorname{Van} 3 \mathrm{C} 1$ & Ucluelet Inlet, CA & $48^{\circ} 56^{\prime} \mathrm{N}, 125^{\circ} 33^{\prime} \mathrm{W}$ & 19/05/10 & KP150102 & N/A & KP150031 \\
\hline West1C2 & Aberdeen, US & $46^{\circ} 58^{\prime} \mathrm{N}, 123^{\circ} 48^{\prime} \mathrm{W}$ & $20 / 05 / 10$ & KP150103 & KP149960 & KP150032 \\
\hline West3B3 & Waldport, US & $44^{\circ} 25^{\prime} \mathrm{N}, 124^{\circ} 04^{\prime} \mathrm{W}$ & 20/05/10 & KP150104 & KP149961 & KP150033 \\
\hline \multicolumn{7}{|l|}{ P. allisonii } \\
\hline Jamaica2 & Dunns River Falls, JM & $18^{\circ} 24^{\prime} \mathrm{N}, 077^{\circ} 08^{\prime} \mathrm{W}$ & $13 / 04 / 10$ & JN201575 & JN201583 & JN201591 \\
\hline PanamaA3 & $"$ & $"$ & $13 / 04 / 10$ & JN201577 & JN201585 & JN201593 \\
\hline \multicolumn{7}{|l|}{ P. crawfordii } \\
\hline MexSmDia1 & Baja California Sur, MX & $26^{\circ} 12^{\prime} \mathrm{N}, 111^{\circ} 18^{\prime} \mathrm{W}$ & 15/09/09 & JN201579 & JN201587 & JN201595 \\
\hline
\end{tabular}


Table 1 Identities, sources and isolation dates of Paralia clones (Continued)

\begin{tabular}{|c|c|c|c|c|c|c|}
\hline \multicolumn{7}{|c|}{ P. fenestrata } \\
\hline MexLgDia & $"$ & $"$ & 15/09/09 & N/A & N/A & KP150017 \\
\hline \multicolumn{7}{|c|}{ Stephanopyxis palmeriana } \\
\hline CCMP0814 & Gulf of Mexico, US & $28^{\circ} 37^{\prime} \mathrm{N}, 89^{\circ} 45^{\prime} \mathrm{W}$ & 02/07/80 & KP193457 & AY485527 & KP253080 \\
\hline
\end{tabular}

and the marginal linking spines $(\mathrm{n}=12 ; \bar{x}=8.1$ in $10 \mu \mathrm{m}$; range $=6.6-9.6$ in $10 \mu \mathrm{m}$ ).

Detailed description of frustule morphology based on SEM images of our clones: In the 15 cultures examined, straight chains were formed of interlocking cells (Figure 3A); each cell contained 4-6 discoid chloroplasts (Figure 3B). Chains could often reach $>100$ cells, but most were $<30$ cells. Frustules were cylindrical and strongly silicified, 5.4-20.2 $\mu \mathrm{m}$ in diameter and 5.5-9.7 $\mu \mathrm{m}$ in pervalvar axis. Two types of valves were found, intercalary (Figures $3 \mathrm{C}$, E, G, and H; 4C) and separation (Figures 3D; 4A and B), each with two forms, relief (long, slender marginal spines, Figures $3 \mathrm{E} ; 4 \mathrm{~A}$ ) and intaglio (short and blunt marginal spines, Figure $3 \mathrm{C}$ and $\mathrm{D})$. Capitate marginal linking spines (5.9-10.0 in $10 \mu \mathrm{m}$; Figure $3 \mathrm{C}$ and G, arrow), occurred only along the face margin of intercalary valves and fit into notches (Figure 3E [arrow] and G [black arrowhead]) between the marginal, short and blunt, square-shouldered spines of a sibling valve. An inner ring of baculiform elevations or internal linking spines of varied size, 2.3-11.5 in $10 \mu \mathrm{m}$, tapered in height towards the unadorned valve centre. The "internal" linking spines are so named because they are internal relative to the marginal linking spines. The marginal and internal linking spines of sibling valves interlocked to keep cells in colonies (Figure 4C), albeit with a different "holding" strength. Marginal linking spines are absent on separation valves. Normally, two concentric rings of larger and smaller pores were present at the valve face margin of intercalary valves (Figure $3 \mathrm{C}$ and $\mathrm{E}$ ).

Separation valves had smooth valve faces. They carried only a pericentral ring of internal spines in the form of noduliform protrusions (Figure 3D) connecting sibling separation valves (Figure 4B). Generally, only one ring of regular, medium-size pores was present on these valves (Figure 3D). The valve face and the mantle met at an approximately right angle, forming a relatively flat, cylindrical girdle outline of the frustule (e.g., Figure 4A).

All valves' basal silica layer was perforated by small, regularly-organised poroid areolae in a decussate pattern of pores (Figure 3F, arrow), still visible on the mantle in fully formed valves of some specimens (Figure 4C, arrow); 2.7-3.6 in $1 \mu \mathrm{m}$ (Figure 4D, arrowhead). Externally, the

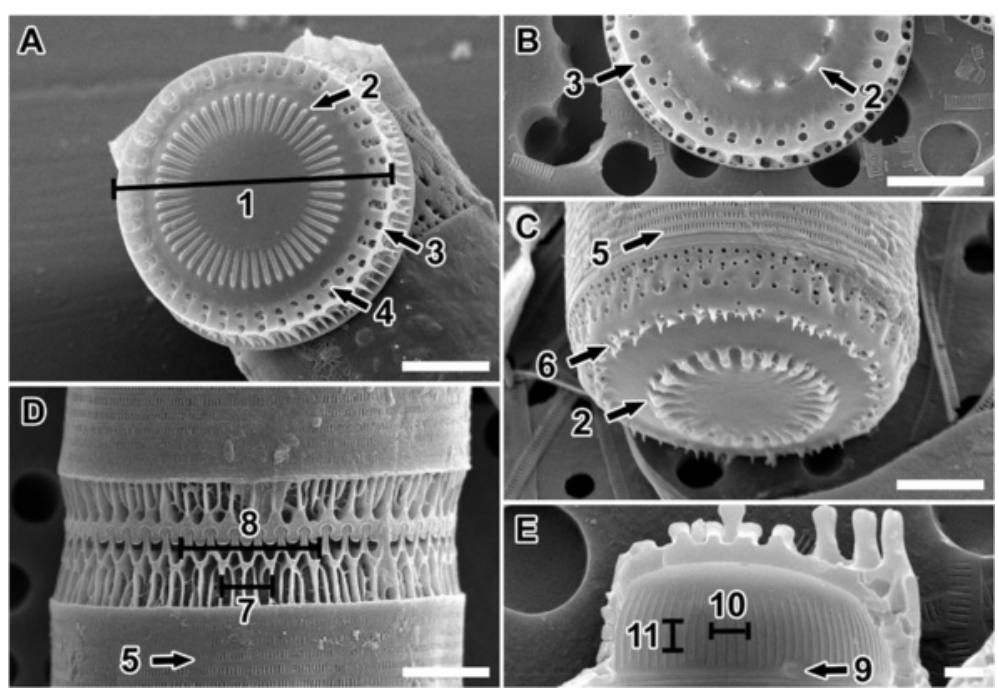

Figure 1 SEM images illustrating the frustule characters examined and quantified in this study. (A) intercalary valve face. $1=$ diameter; $2=$ internal linking spines (so named because they are located internally relative to the marginal linking spines) in the form of baculiform elevations in intercalary valves and as noduliform protrusions in separation valves; $3=$ external ring of marginal pores; $4=$ internal ring of marginal pores. (B) separation valve face. (C) Tilted view of separation valve. $5=$ slits in copula; $6=$ valve face prickles. (D) mantle. $7=$ four fenestrae; $8=$ six marginal linking spines. (E) Internal view of valve. $9=$ rimoportulae; $10=$ three internal striae; $11=$ three internal striae pore areolae. (A) Paralia guyana 'servidei', (B,E) P. guyana 'smooth' and (C,D) P. guyana 'capebreton' genodemes. Scale bars $=5 \mu \mathrm{m}$ (A-D), $1 \mu \mathrm{m}$ (E). 


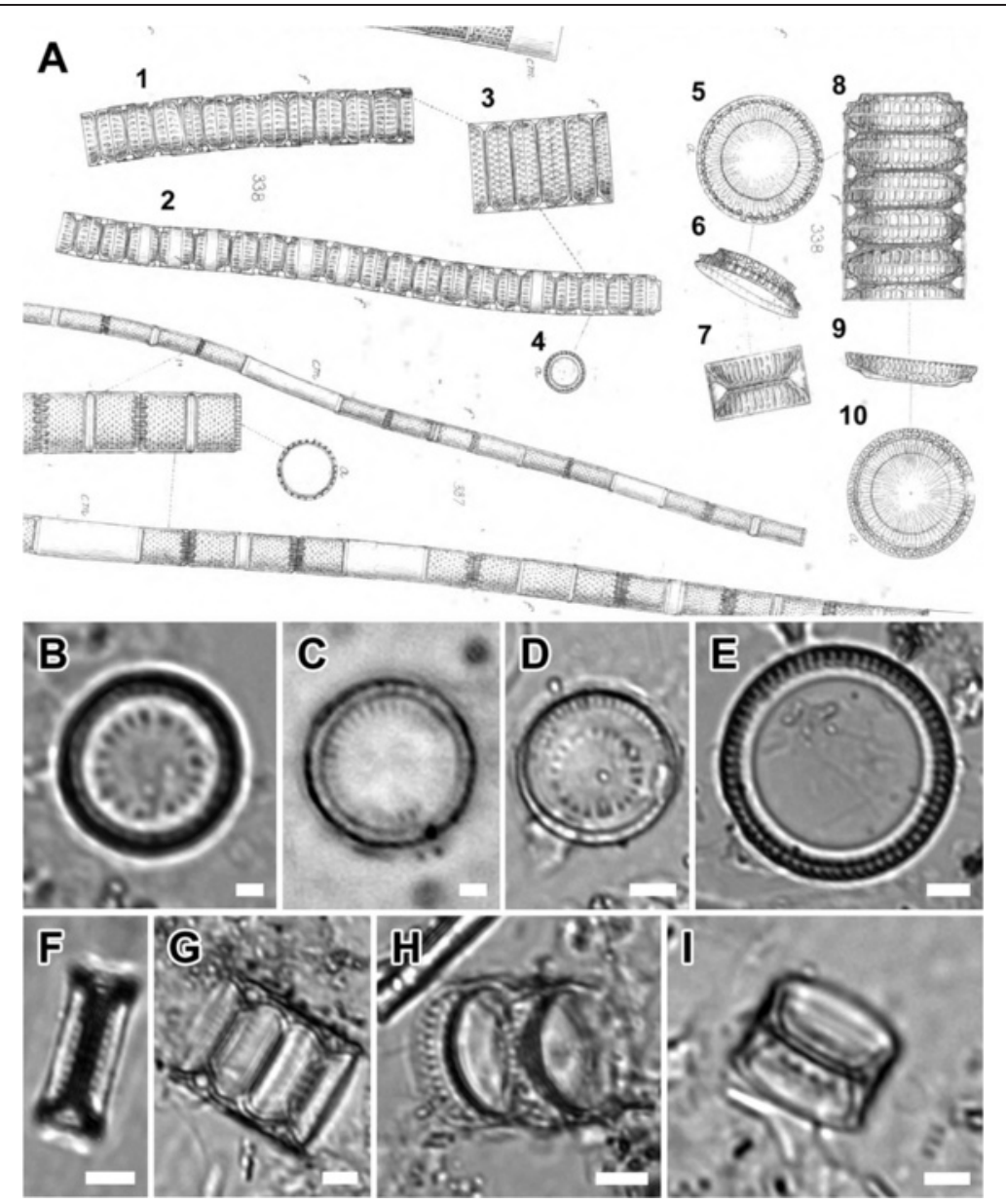

Figure 2 Paralia specimens from W. Smith's ([17], pl. 53, figure 338) drawings and BM1021 preparation. The BM1021 preparation, containing P. marina from Kinsale Harbour, Ireland (circa ca. 1850) is the generitype for Paralia [15]. Valves and chains labelled 1-4 and 7 correspond to Smith's concept of P. marina, as deduced from BM1021 preparation. Those labelled 5, 6 and 8-10 show fenestrae which correspond more closely to P. sulcata s.s. [10] and P. fenestrata [12]. (A) Smith's ([17], pl. 53, figure 338) drawings of valves and chains. (B-D) Valve face view. (B,C) Large and smaller intercalary valves. (D) Separation valve. (E) Internal view of valve. (F-I) Mantle of interlocked valves. (F-H) Intercalary. (I) Separation. Scale bars $=5 \mu \mathrm{m}$ (D-I), $2 \mu \mathrm{m}$ (B,C).

pairs of mantle striae were separated by siliceous outcroppings (Figure 4C, black arrowheads) superimposed over the basal silica layer. An interspaced pair of striae and siliceous outcroppings formed narrow fenestrae (6.0-15.4 in $10 \mu \mathrm{m})$. Mantle fenestration was most pronounced in incompletely silicified valves (compare Figures 3G and 4C with $3 \mathrm{H}$ ) and when observed in SEM. In fully silicified valves, fenestrae were cached with a siliceous cover dotted with simple pores (Figure $3 \mathrm{H}$ ). Even though fenestrae were obscured in SEM, they were nonetheless generally resolvable in LM (Figure 3A). Cingulae were composed of 8-9 copulae and each copula carried regularly-spaced, centrally-located slits (Figure 3G, white arrowhead), 38.5-68.7 in $10 \mu \mathrm{m}$.

Internally, the mantle rim was smooth (Figure 4D). Irregularly-spaced, simple and small rimoportulae, 1.12.5 in $10 \mu \mathrm{m}$, were positioned just below the mantle overhanging edge (Figure 4D, arrows). Minute external openings of the rimoportulae were observed in many valves (Figure $4 \mathrm{C}$, white arrowhead). Internally, striae began below the mantle edge and ran perpendicular to it but few pore areolae were replaced by rimoportulae when they were present (31.1-60.0 in $10 \mu \mathrm{m})$. Striae varied in length and did not extend onto the face of the completely silicified valve. A summary of the clone metrics is presented in Table 2.

Distribution: Paralia marina was the most widely distributed species of the Paralia taxa examined in this study: five sites throughout Europe and one site in Uruguay, New Zealand and eastern Canada (Table 1, Figure 9). In addition, chains of P. marina was recovered throughout all three TAVs (96\% of total cells encoun-

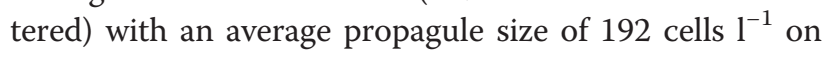
the final day of each TAV. 

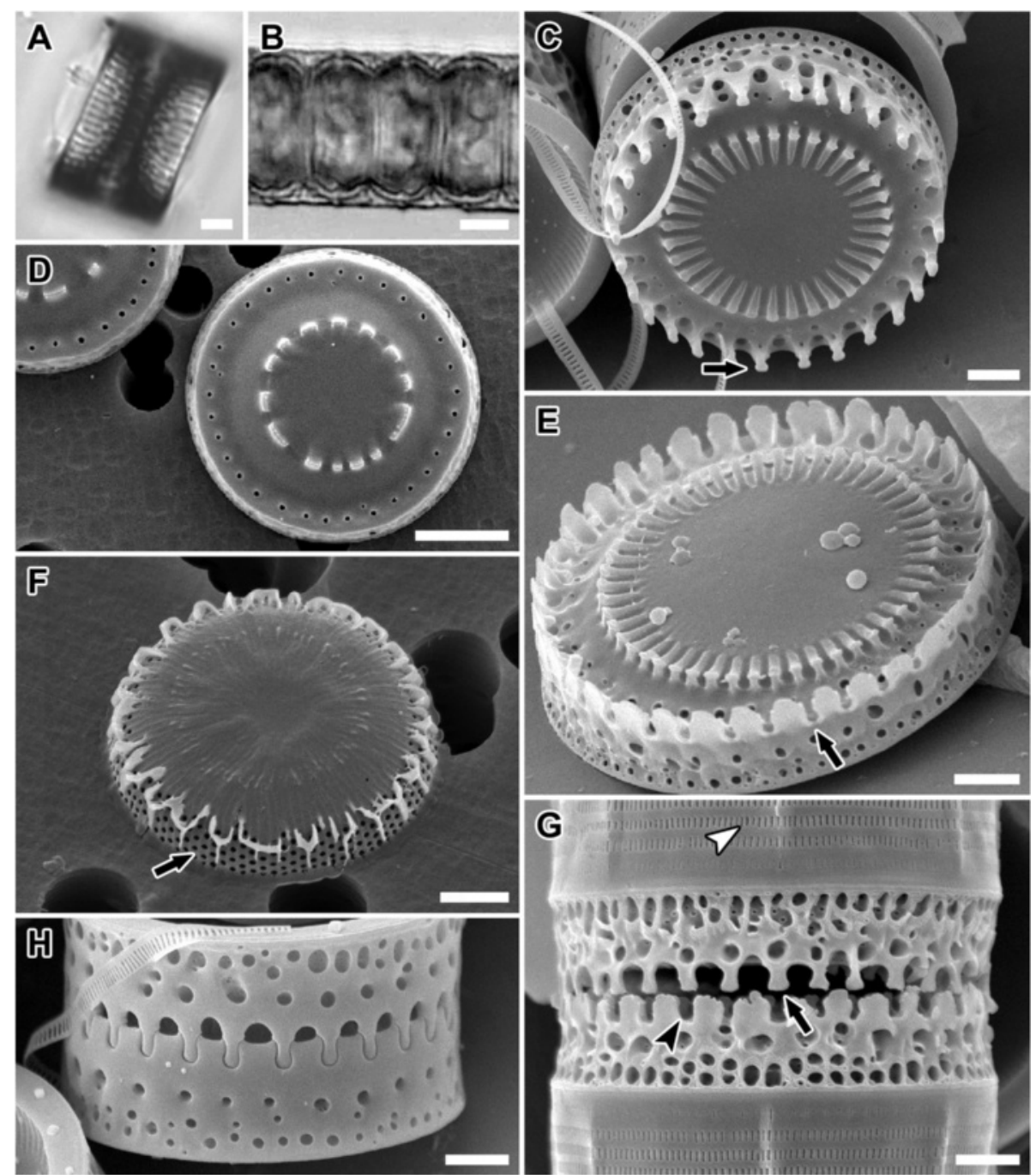

Figure 3 LM and SEM images of Paralia marina. (A,B) CCAP 1059/2. Light micrographs. (A) Interlocked sibling valves showing narrow fenestrae. (B) Chain of live cells showing the outline of the cell lumen. (C-H) Scanning electron micrographs. Epitype specimens, B40 0040792. (C-F) Valve face view. (C) Uru6. Smooth intercalary valve in relief showing long, slender and capitate marginal linking spines (arrow). (D,E) Intaglio valves (square-shouldered, short and blunt spines [12]). (D) Par1. Separation valve with smooth valve face and unadorned margin. (E) Intercalary valve showing marginal ridge formed by blunt, short spines with notches (arrow) between them which interlock with end of long, slender marginal spines. (F) Uru1. Incompletely silicified separation valve with rows of pores in a decussate pattern on the valve mantle (arrow). (G,H) Girdle view of sibling intercalary valves. (G) Helgo3. Nearly interlocked valves with long, slender capitate marginal linking spines (arrow), narrow fenestrae exposed, marginal square-shouldered, blunt spines with notches (black arrowhead) and simple slits in copulae (white arrowhead).

(H) Uru6. Completely silicified interlocked sibling valves with fenestrae obscured. Scale bars =5 4 m (B,D), $3 \mu \mathrm{m}$ (A), $2 \mu \mathrm{m}$ (C,E-H).

Comparison to morphology of other species: Paralia marina is morphologically indistinguishable from the 'smooth' extant $P$. guyana genodeme (described below), from Miocene P. obscura MacGillivary [10] and from extant natural specimens named $P$. sulcata (illustrated in figures eleven to twenty-five in [12]). Unfortunately, genetic data is not available for the latter two entities and therefore their relationship to $P$. marina cannot be resolved. Paralia marina differs from the members of the Paralia longispina species complex by the absence of marginal spines on separation valves. Also, fenestrae are more regularly elliptical-shaped in $P$. longispina-like species than in $P$. marina. Fenestrae shape and size again differ between $P$. marina and $P$. fenestrata and recently lectotypified $P$. sulcata $[10]$ as the latter two have U-shaped fenestrae that are exposed (not covered by a siliceous overlayer) even in completely silicified valves. Unfortunately, fenestra morphology on valves of $P$. sulcata s.s. with similar cell sizes as $P$. marina examined here is unknown at this time, but in P. fenestrata even very small valves demonstrate open, large fenestra (Kaczmarska, unpublished results), clearly different from those of $P$. 


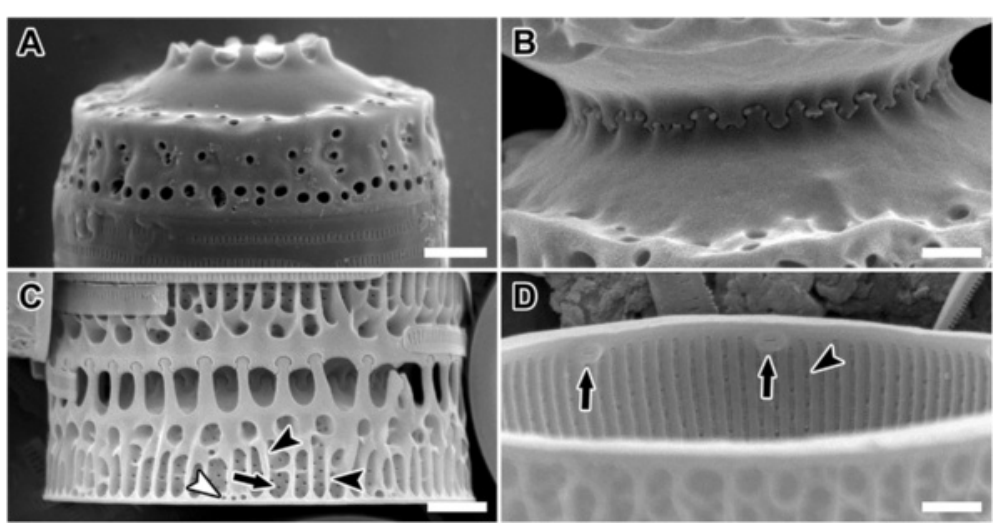

Figure 4 SEM images of Paralia marina. Epitype specimens, B40 0040792. (A-C) Mantle view. (A) Uru1. Profile of smooth and spineless separation valve with obscured fenestrae. (B) Helgo1. Interlocking noduliform protrusions of sibling separation valves. (C) Helgo3. Weakly silicified intercalary valves showing areolae perforating basal silica layer (arrow), siliceous outcroppings (black arrowheads) and external pores of rimoportulae (white arrowhead) which are usually more spaced apart than on this specimen; fenestrae unobscured. (D) Helgo 1. Internal valve view with rimoportulae (arrow) and striae pores (arrowhead). Scale bars $=2 \mu \mathrm{m}(\mathbf{A}, \mathbf{C}), 1 \mu \mathrm{m}(\mathbf{B}, \mathbf{D})$.

marina. Unlike P. elliptica, which has an elliptical to kidney-shaped valve face, $P$. marina has a circular outline. Marginal linking spines of intercalary valves are deeply capitate in $P$. capitata in contrast to subtle capitate spines in P. marina.

Molecularly, $P$. marina is quite divergent from $P$. guyana (see below), P. allisonii and P. crawfordii [6] in the examined sequences of $18 \mathrm{~S}(\mathrm{~d}=0.02$ [representing two base pair (bp) differences per $100 \mathrm{bp}$ sequence segment], $d=0.02, d=0.03$, respectively), ITS ( $d \geq 0.34$ [depending on the genodeme], $d=0.35, d=0.37$, respectively) and $r b c \mathrm{~L}$ ( $\mathrm{d} \geq 0.05$ [depending on the genodeme], $\mathrm{d}=0.05$, $\mathrm{d}=0.06$, respectively). There are also structural differences in ITS2 secondary structure models between $P$. marina and the other three species; $P$. marina has five helices whereas the other species have four. In addition, even the superconserved motif on the $5^{\prime}$ side of Helix III differs between $P$. marina (UGGU), $P$. allisonii and $P$. crawfordii (AGGU, [6]) and P. guyana (AGGA). Furthermore, Compensatory Base Changes (CBCs) are present between $P$. marina vs. $P$. allisonii and $P$. marina vs. $P$. guyana; basal portions of each in Helix I and Helix IV and near the terminal loop in Helix II, which are the few areas of relative conservation.

Paralia guyana MacGillivary sp. nov. (Figures 5, 6, 7, 8; Table 2).

Holotype: Material of culture "SV7" cleaned and Hyrax embedded slide (CANA 107802), National Herbarium of Canada, Phycology Section, Canadian Museum of Nature, Ottawa, Canada. Holotype specimen illustrated in Figure 5A. The entire ITS region and sequence fragments of the $r b c \mathrm{~L}$ and $18 \mathrm{~S}$ rRNA genes and voucher specimens were deposited in GenBank via the BOLD System (accession numbers in Table 1).
Type locality: Phytoplankton sample from Shediac Valley, Gulf of St. Lawrence, Canada $\left(47^{\circ} 20^{\prime} \mathrm{N}, 64^{\circ} 25^{\prime} \mathrm{W}\right)$.

Isotype: SEM preparation B40 0040793 (Figure 5, C-I; Figure 6, C-I; Figure 7, C-J; Figure 8, C-G) ex cultura, deposited at the BGBM.

Etymology: Species dedicated to the first author's maternal grandparents (surname Guy) on the occasion of their 55th wedding anniversary.

Diagnosis: Valves circular, forming straight chains. Separation valve face free of marginal spines, but may carry prickles. In SEM preparations, fenestrae obscured with a siliceous covering in intact specimens. Secondary structure of the nuclear rDNA ITS2 transcript has four helices, a combined $\mathrm{U}: \mathrm{C}$ and $\mathrm{C}: \mathrm{C}$ mismatch in Helix II and AGGA super-conserved motif on the $5^{\prime}$ side of Helix III.

Description of frustule morphology: Fifty-seven clones were examined for this species. Both intercalary and separation valves were morphologically indistinguishable from that of $P$. marina (above), both internally and externally in all 10 metric characters examined (Table 2). The only non-metric morphological difference found was that some separation valves of this species carried prickles [Figure 6D, E, G and Figure 7D, E, H and Figure 8D, arrow(s)] of various size, in addition to those valves that had smooth valve faces (Figure 5D). When present, prickles were most commonly located between the valve face margin and the pericentral ring of noduliform protrusions or on the mantle (i.e., Figure $8 \mathrm{~F}$ ).

Distribution: Recovered from 37 sites on the Atlantic and Pacific coasts of North America (Table 1, Figure 9).

Comparison to other species: This species is morphologically semi-cryptic or cryptic (depending on which of the four genodemes are used in the comparison, see below), yet molecularly it is strongly divergent from $P$. 

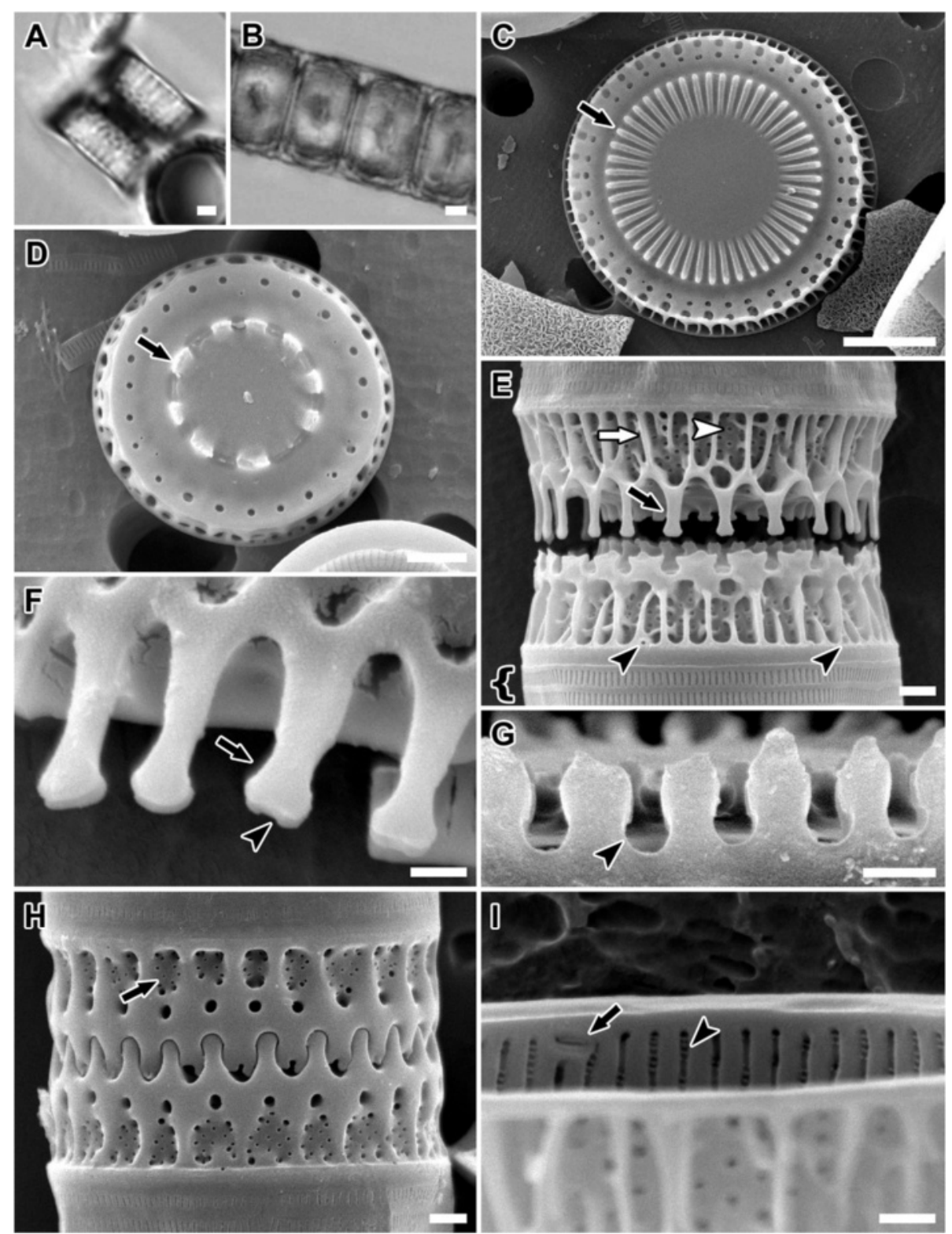

Figure 5 LM and SEM images of Paralia guyana 'smooth' valves. (A,B) SV7. Light micrographs. (A) Holotype specimen of P. guyana, CANA 107802. Smooth valve face sibling separation valves. (B) A chain of live cells. (C-I) Scanning electron micrographs. Isotype specimens of $P$. guyana B40 0040793. (C,D) Valve face of intercalary (C; EC112-3) and separation (D; EC106-1) valves with arrows marking central baculiform elevations and noduliform central protrusions, respectively. (E) EC105-2. Mantle view of relatively weakly silicified and slightly separated sibling intercalary valves with unobscured fenestrae. Black arrow indicates long, capitate marginal linking spines. Black arrowheads point to external pores of rimoportulae. Siliceous outcropping (white arrow) and pore (white arrowhead) in basal silica layer are also evident. Parenthesis indicates cingulum. (F) YH1. Marginal linking spine (arrow) with slit at its apex (arrowhead). (G) EC109-2. Notches (arrow) between the short, blunt, squared-shoulder spines in relief intercalary valve. (H) Van4B3. Mantle view of interlocked sibling intercalary valves with arrow denoting shallow depressions in the siliceous covering of fenestrae. (I) GA3. Internal view of valve showing slit of rimoportulae (arrow) and striae pores (arrowhead). Scale bars $=2 \mu \mathrm{m}(\mathbf{A}-\mathbf{D}), 1 \mu \mathrm{m}(\mathbf{E}, \mathbf{G}, \mathbf{H}), 0.5 \mu \mathrm{m}(\mathbf{F}, \mathbf{I})$.

marina (see above and below). Comparison of the ITS2 secondary structures of all species for which they are available ( $P$. guyana vs. $P$. allisonii and $P$. guyana vs. $P$. crawfordii) yields two and one $\mathrm{CBC}(\mathrm{s})$ in the basal part of Helix IV, respectively, among other differences (compare ITS2 secondary structures in [6], figure 45 ellipse). Within P. guyana there were four molecularly, and in one case morphologically, defined demes. They are described immediately below.

Paralia guyana 'smooth' genodeme (Figure 5A-I).

Material: Grown in culture, the same as P. guyana s.l. (above).

Morphology: Aside from having a smooth separation valve face, this genodeme was morphologically cryptic 

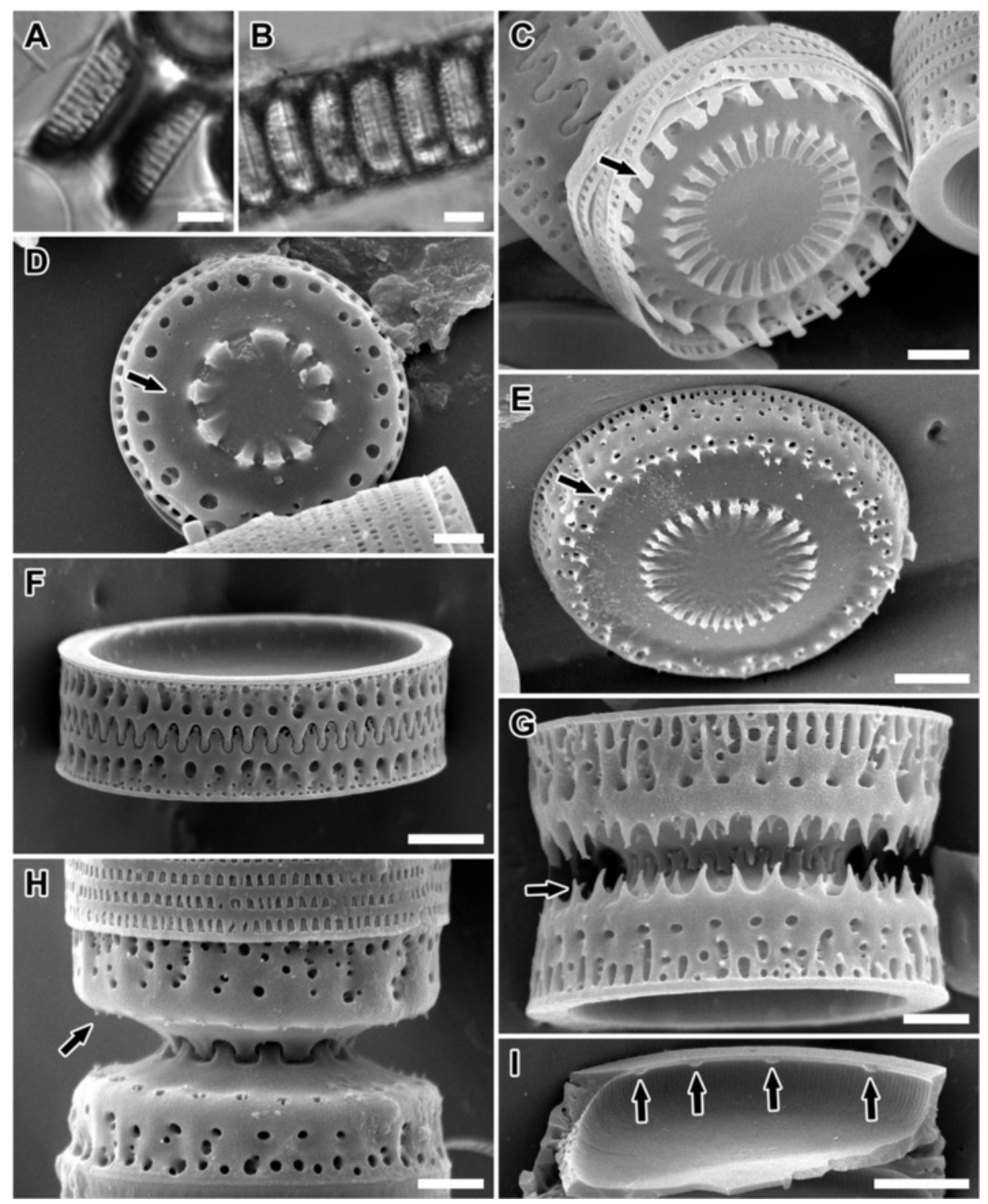

Figure 6 LM and SEM images of Paralia guyana 'caisn' valves. (A,B) VanA4. Light micrographs. (A) Sibling separation valves. (B) A chain of live cells. (C-I) Scanning electron micrographs. Isotype specimens of $P$. guyana B40 0040794. (C-E) Valve face. (C) Van2B2. Intercalary valve with slightly capitate, long marginal linking spines (arrow) and copulae. (D) Van2B2. Nearly smooth separation valve with a few minute prickles (arrow). (E) Van4A2. Separation valve showing small, abundant prickles (arrow). (F) Van4A2. Interlocked sibling intercalary valves with obscured fenestrae. $(\mathbf{G}, \mathbf{H})$. Interlocked sibling separation valves showing variation in size of prickles on the valve face margin. (G) West11B4. Well developed prickles (arrow); most fenestrae of topmost valve unobscured. (H) Van2B2. Minute prickles (arrow); obscured fenestrae. (I) Van4A2. Internal view of valve with irregularly spaced rimoportulae (arrows). Scale bars $=5 \mu \mathrm{m}(\mathbf{A}, \mathbf{B}, \mathbf{E}, \mathbf{F}, \mathbf{I}), 2 \mu \mathrm{m}(\mathbf{C}, \mathbf{D}, \mathbf{G}, \mathbf{H})$.

with the other genodemes of P. guyana. It is also morphologically cryptic in both separation and intercalary valves with $P$. marina. See Table 2 for morphometric ranges.

Molecular signature: Compared to other genodemes of P. guyana, 'smooth' had an autapomorphy in helices I and II of ITS2: 5 '-CUUUGUCUUGCGUUGGCCUGUG UCGCGGACC-3' (31 bp).

Distribution: Found in 30 sites on the Atlantic and Pacific coasts of North America (Table 1, Figure 9).

Paralia guyana 'caisn' genodeme (Figure 6A-I).
Material: Culture "VanA4" cleaned and Hyrax embedded slide (CANA 107803), National Herbarium of Canada, Phycology Section, Canadian Museum of Nature, Ottawa, Canada. SEM preparation B40 0040794 deposited at the BGBM.

Morphology: Had variable-sized prickles on the separation valve face which were only detectable in SEM. Morphologically cryptic with the 'capebreton' and 'servidei' genodemes, (see below and in Table 2).

Molecular signature: Autapomorphy in helices I and II of ITS2: 5'-CUGUGUCUUGAGUUGGCCUGUGUCGC 


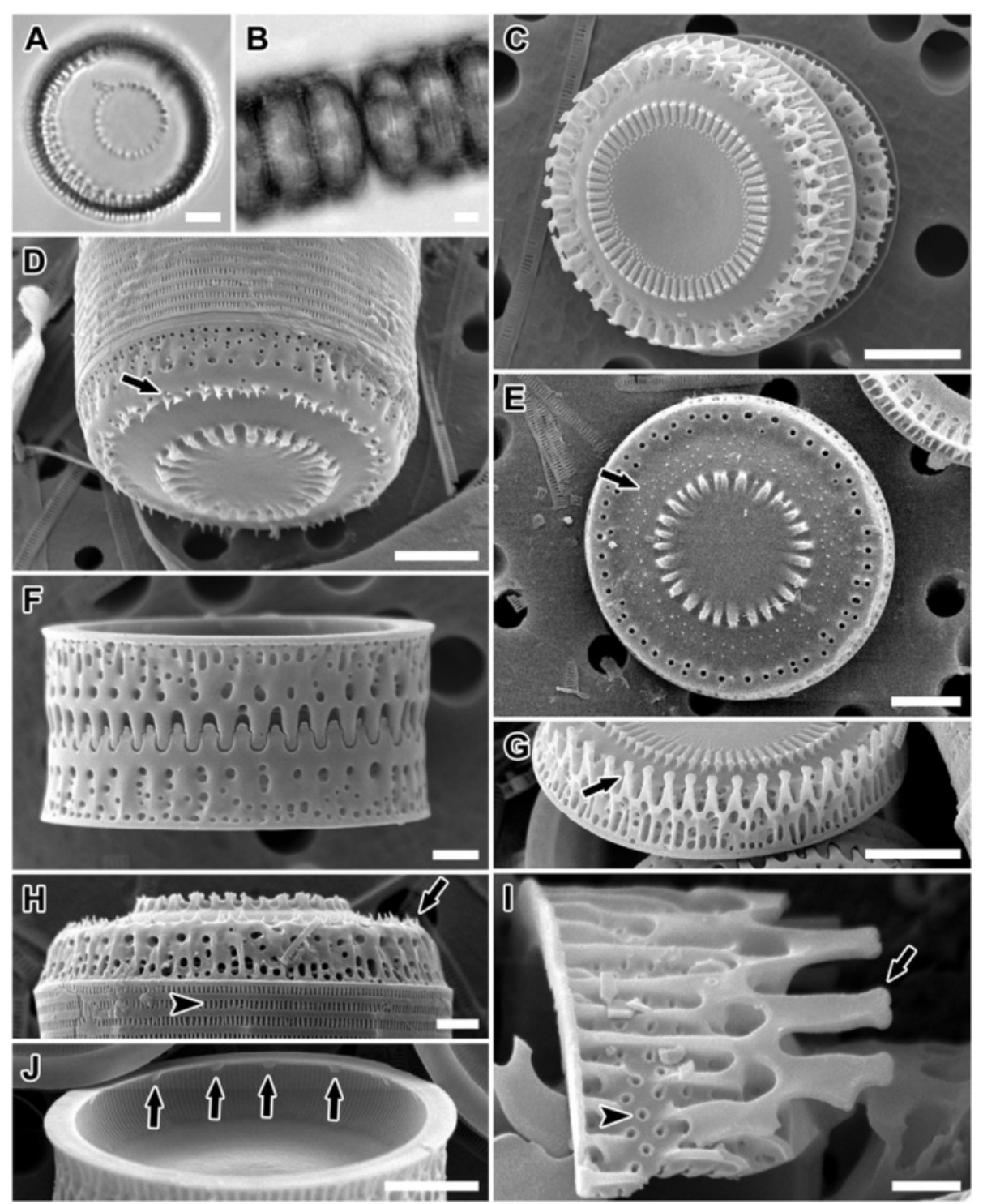

Figure 7 LM and SEM images of Paralia guyana 'capebreton' valves. (A,B) GP1. Light micrographs. (A) Valve face view of separation valve. (B) A chain of live cells. (C-J) Scanning electron micrographs. Isotype specimens of P. guyana B40 0040795. (C-E) Valve face. (C) GP1. Intercalary valve. (D) GP6. Separation valve with marginal prickles (arrow). (E) GP2. Separation valve with minute prickles throughout valve face (arrow). (F) GP1. Interlocked sibling intercalary valves; fenestrae covered. (G) GP6. Tilted valve face view of intercalary valve with capitate marginal spines (arrow); fenestrae uncovered. (H) GP6. Mantle view of separation valve with prickles (arrow) and slits in copulae (arrowhead). (I) GP4. Portion of mantle of incompletely silicified intercalary valve with marginal spines (arrow), pores of basal silica layer (arrowhead) and exposed fenestrae. (J) GP5. Internal view of valve showing positions of rimoportulae (arrows). Scale bars $=5 \mu \mathrm{m}(\mathbf{A}-\mathbf{E}, \mathbf{G}, \mathbf{J}), 2 \mu \mathrm{m}(\mathbf{F}, \mathbf{H}), 1 \mu \mathrm{m}(\mathbf{I})$.

GGAGC-3' (31 bp). In combination, three transversions at sites 22,30 and 49 of this sequence and transversions (site 371) and transitions (sites 439 and 475) in the $r b c \mathrm{~L}$ fragment differentiated it from the other genodemes. The entire ITS region and sequence fragments of the $r b c \mathrm{~L}$ and 18S rRNA genes and voucher specimens were deposited in GenBank via the BOLD System (accession numbers in Table 1).

Distribution: Found at four sites on the Pacific coast of North America (Table 1, Figure 9).
Paralia guyana 'capebreton' genodeme (Figure 7A-J). Material: Culture "GP1" cleaned and Hyrax embedded slide (CANA 107804), National Herbarium of Canada, Phycology Section, Canadian Museum of Nature, Ottawa, Canada. SEM preparation B40 0040795 deposited at the BGBM.

Morphology: Had variable-sized prickles on the separation valve face which were only detectable in SEM. Morphologically cryptic with the genodemes 'caisn' (above) and 'servidei' (below), and in Table 2. 

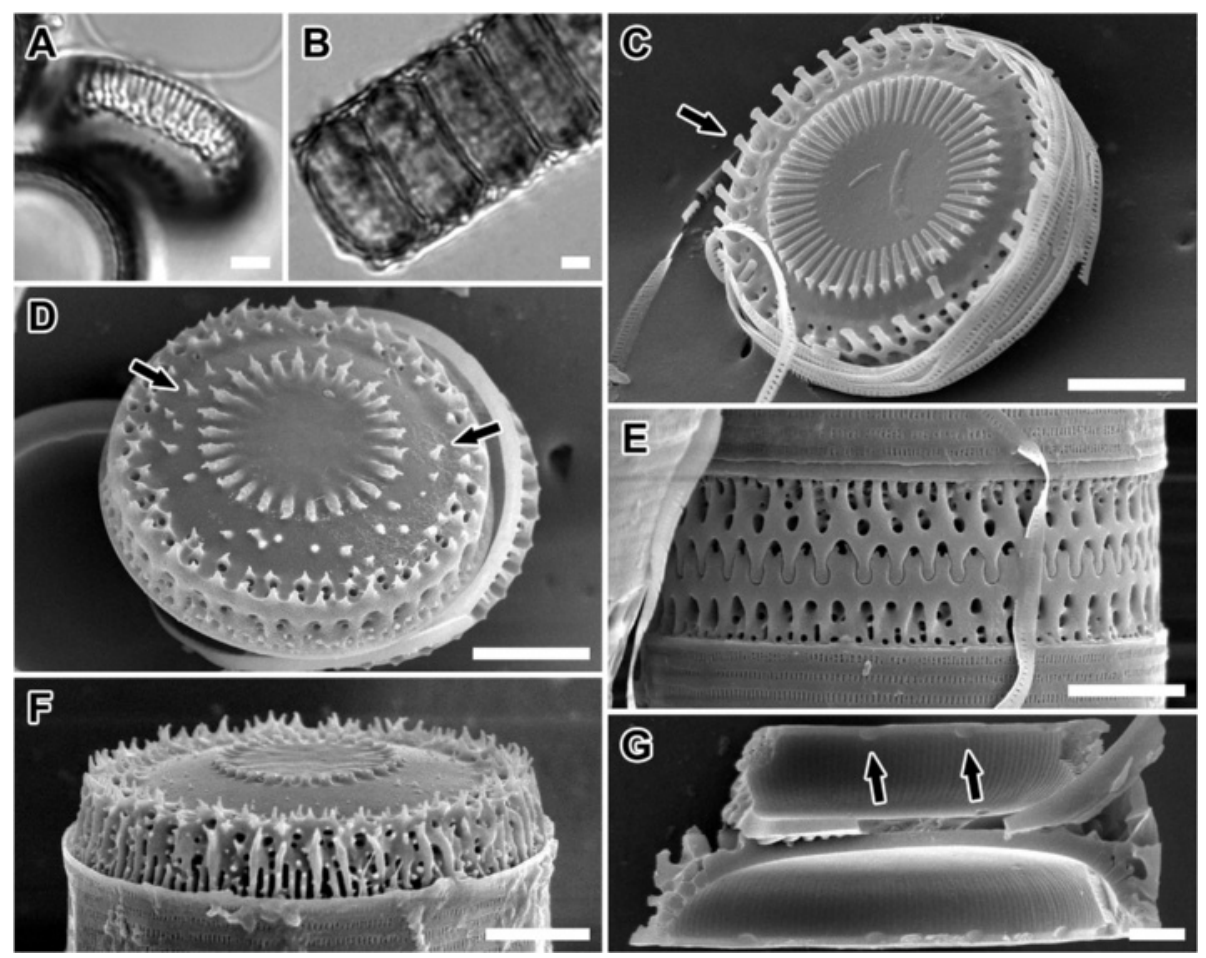

Figure 8 LM and SEM images of Paralia guyana 'servidei' valves. (A,B) Van3C1. Light micrographs. (A) Tilted separation valve showing valve face and mantle. Note that even the characteristically pronounced prickles in this genodeme are not detectable on LM image; fenestrae notable. (B) A chain of live cells. (C-G) Scanning electron micrographs. Isotype specimens of P. guyana B40 0040796. (C,D) Van3C1. Valve face view. (C) Intercalary valve face with capitate, slender marginal spines (arrow). (D) Separation valve with pronounced prickles (arrows). (E) West1C2. Interlocked sibling intercalary valves and cingulae; upper valve with some fenestrae unobscured. (F) West1C2. Mantle view of relief separation valve showing prickles on the mantle. (G) West1C2. Internal view of valve with rimoportulae (arrows) and striae. Scale bars =5 $\mu \mathrm{m}$ (A-F), $2 \mu \mathrm{m}$ (G).

Molecular signature: Autapomorphy in helices I and II of ITS2: 5'-CAUUGUCUUGCGUUGGCCUGUGUCGC GGAGC-3' (31 bp). Combined, two transversions at sites 21 and 49 of this sequence differentiate it from other demes. The entire ITS region and sequence fragments of the $r b c \mathrm{~L}$ and 18S rRNA genes and voucher specimens were deposited in GenBank via the BOLD System (accession numbers in Table 1).

Distribution: Found at one site in a salt-water lake in eastern Canada (Table 1, Figure 9).

Paralia guyana 'servidei' genodeme (Figure 8A-G).

Material: Culture "Van3C1" cleaned and Hyrax embedded slide (CANA 107805), National Herbarium of Canada, Phycology Section, Canadian Museum of Nature, Ottawa, Canada. SEM preparation B40 0040796 deposited at the BGBM.

Morphology: Had stout, variable-sized prickles on the separation valve face which were only detectable in SEM when prickles were short. It is morphologically cryptic with genodemes 'caisn' and 'capebreton', (see above and in Table 2).

Molecular signature: Six hemi-compensatory base changes, one in Helix II, two in Helix III and three in Helix IV of the ITS2 transcript secondary structure differentiate it from other genodemes. The entire ITS region and sequence fragments of the $r b c \mathrm{~L}$ and $18 \mathrm{~S}$ rRNA genes and voucher specimens were deposited in GenBank via the BOLD System (accession numbers in Table 1).

Distribution: Found at three sites on the Pacific Northwest coast of North America (Table 1, Figure 9).

\section{Morphometric analyses}

Eight species, two from this study and six from related species examined earlier [6,10], were analyzed metrically using SEM images using ten metric valve characters also used in recent taxonomic studies of this genus $([6,10,12] ;$ Table 2$)$. This is much more than a routine diatom metric analysis (e.g., valve length, width, striae and areolae) and demonstrated both the wide range of intraspecific morphological variation and the considerable overlap between these taxa. Hierarchical clustering of morphometrically continuous data (i.e., number of rimoportulae in $10 \mu \mathrm{m}$, Table 2) rendered approximately unbiased (AU) multiscale bootstrap values and ordered clones into three main clusters, namely, C1, C2 and C3 (Figure 10), represented by two, four and 31 clones respectively. The smallest cluster $(\mathrm{p}=0.98), \mathrm{C} 1$, consisted 
Table 2 Summary of metric characters of Paralia species in this study

\begin{tabular}{|c|c|c|c|c|c|}
\hline \multirow[b]{2}{*}{ Genodeme } & \multirow[t]{2}{*}{ P. marina } & \multicolumn{4}{|l|}{ P. guyana } \\
\hline & & 'smooth' & 'caisn' & 'capebreton' & 'servidei' \\
\hline \# of clones examined & 15 & 41 & 7 & 6 & 3 \\
\hline \multicolumn{6}{|l|}{ Character } \\
\hline \multirow[t]{2}{*}{ Valve diameter $(\mu \mathrm{m})$} & $12.2(3.4)$ & $11.5(2.9)$ & $15.3(5.2)$ & $18.6(4.2)$ & $19.9(2.5)$ \\
\hline & 5.4-20.2; 199 & $6.9-22.9 ; 571$ & $9.0-26.9 ; 147$ & 9.2-23.8; 109 & $13.7-24.1 ; 47$ \\
\hline \multirow[t]{2}{*}{ Pervalvar axis $(\mu \mathrm{m})$} & $7.6(1.1)$ & $7.7(1.1)$ & $15.3(5.2)$ & $10.4(4.4)$ & 7.6 (0.99); \\
\hline & $5.5-9.7 ; 31$ & $4.9-11.3 ; 132$ & $9.0-26.9 ; 14$ & $6.4-10.3 ; 17$ & $6.5-8.5 ; 5$ \\
\hline \multicolumn{6}{|l|}{ Valve face } \\
\hline \multirow[t]{2}{*}{ Internal linking spines in $10 \mu \mathrm{m}$} & $5.9(2.5)$ & $6.4(3.1) ;$ & 6.0 (2.9); & 7.1 (2.9); & $7.0(3.3)$ \\
\hline & 2.3-11.5; 116 & $1.2-11.9 ; 312$ & $2.8-11.7 ; 83$ & $3.2-12.0 ; 68$ & $2.2-13.8 ; 32$ \\
\hline Separation valve prickles present & No & No & Mostly & Mostly & Mostly \\
\hline \multicolumn{6}{|l|}{ Valve mantle external } \\
\hline \multirow[t]{2}{*}{ Marginal linking spines in $10 \mu \mathrm{m}$} & $7.7(0.87)$ & $8.2(0.92)$ & $7.8(0.78)$ & $7.7(0.81)$ & $7.6(0.67)$ \\
\hline & $5.9-10.0 ; 42$ & 5.7-10.4; 197 & $6.5-10.2 ; 23$ & $6.0-9.9 ; 38$ & $6.4-8.8 ; 14$ \\
\hline \multirow[t]{2}{*}{ Fenestrae in $10 \mu \mathrm{m}$} & $10.5(3.4)$ & $8.0(0.81)$ & 9.9 (3.9); & $7.6(0.6)$ & $7.9(1.2)$ \\
\hline & $6.0-15.4 ; 30$ & 5.6-10.3; 191 & $5.9-18.1 ; 17$ & 6.4-8.6; 42 & $6.4-8.9 ; 4$ \\
\hline \multirow[t]{2}{*}{ Cingulum slits in $10 \mu \mathrm{m}$} & $51.6(6.4)$ & $53.8(6.7)$ & $41.2(6.8)$ & $44.7(4.4)$ & $42.6(7.8) ;$ \\
\hline & 38.5-68.7; 108 & $33.5-76.1 ; 335$ & 33.1-61.0; 162 & $36.8-61.0 ; 103$ & $33.7-66.3 ; 16$ \\
\hline \multicolumn{6}{|l|}{ Valve mantle internal } \\
\hline \multirow[t]{2}{*}{ Internal striae in $10 \mu \mathrm{m}$} & $37.4(4.7)$ & $38.6(3.3)$ & $38.0(2.7)$ & $37.7(2.1)$ & 38.9 (3.3); \\
\hline & $31.1-60.0 ; 54$ & $32.8-64.3 ; 177$ & 30.3-43.0; 36 & $33.7-42.7 ; 40$ & $34.3-45.6 ; 14$ \\
\hline \multirow[t]{2}{*}{ Internal striae pores in $1 \mu \mathrm{m}$} & $3.0(0.34)$ & $2.8(0.33)$ & $3.5(0.41)$ & $2.8(0.30)$ & $3.05(0.38)$ \\
\hline & $2.7-3.6 ; 5$ & $2.3-4.1 ; 71$ & 3.0-4.0; 8 & $2.4-3.3 ; 14$ & $2.8-3.5 ; 3$ \\
\hline \multirow[t]{2}{*}{ Rimoportulae in $10 \mu \mathrm{m}$} & 1.9 (0.53); & $2.1(0.48) ;$ & $2.5(0.48)$ & $2.5(0.47)$ & $2.4(0.28)$ \\
\hline & $1.1-2.5 ; 26$ & $0.4-3.6 ; 87$ & $1.5-3.8 ; 27$ & $1.5-3.5 ; 25$ & 1.9-2.9; 11 \\
\hline
\end{tabular}

Values given for mean with standard deviation in parentheses, followed by range and number of measurements.

of Miocene $P$. sulcata s.s. and extant P. fenestrata which both had smooth valve faces on separation valves, but could be distinguished from all other taxa by open, wide, horseshoe-shaped fenestrae. The larger, second cluster, C2 $(\mathrm{p}=0.91)$, included the $P$. longispina-like species, $P$. allisonii and $P$. crawfordii, both of which had triangular marginal spines on the face of separation valves, and one clone from the P. guyana 'caisn' genodeme which did not have marginal spines, but had prickles on the separation valve face (Figure 10). Cluster C3 contained four species and all genodemes of $P$. guyana and may be subdivided into four metrically defined subclusters containing a mixture of species and their genodemes. Each of the sub-clusters (C3a-d) had separation valves possessing various non-metric characters (i.e., presence or absence of prickles or spines on the separation valve face). Sub-cluster $\mathrm{C} 3 \mathrm{a}$ contained only $P$. marina $(\mathrm{p}=1.00)$. On the other hand, sub-cluster C3b $(\mathrm{p}=1.00)$ grouped together four taxa with different separation valve face microarchitecture; smooth (Miocene P. obscura, extant $P$. marina and six clones of the extant 'smooth' genodeme of $P$. guyana), prickly (one clone each of the extant 'caisn' and 'capebreton' genodemes of $P$. guyana) and spiny (extant $P$. ehrmanii). The third sub-cluster, C3c $(\mathrm{p}=0.95)$, contained the three prickly genodemes of $P$. guyana (three, four and two clones of the 'caisn', 'capebreton' and 'servidei' genodemes, respectively). Sub-cluster C3d grouped together seven clones representing the smooth-faced P. marina (two clones), the 'smooth' genodeme of $P$. guyana (one clone) and the three prickly separation valve-faced $P$. guyana genodemes $(\mathrm{p}=1.00)$. Neither metric nor discrete characters measured and evaluated consistently segregated taxa from cluster $\mathrm{C} 3$ in agreement with their genetic signatures (see below).

\section{Sequence analysis}

Amplicons from all three DNA regions, $18 \mathrm{~S}, r b c \mathrm{~L}$ and ITS1, were recovered from all 76 clones (except for $18 \mathrm{~S}$ from two clones of Paralia marina from Trieste, Italy; Table 1). For the 18 chains of Paralia from the TAVs, only the most divergent marker, the ITS region was amplified and analyzed. No intraspecific divergence among 


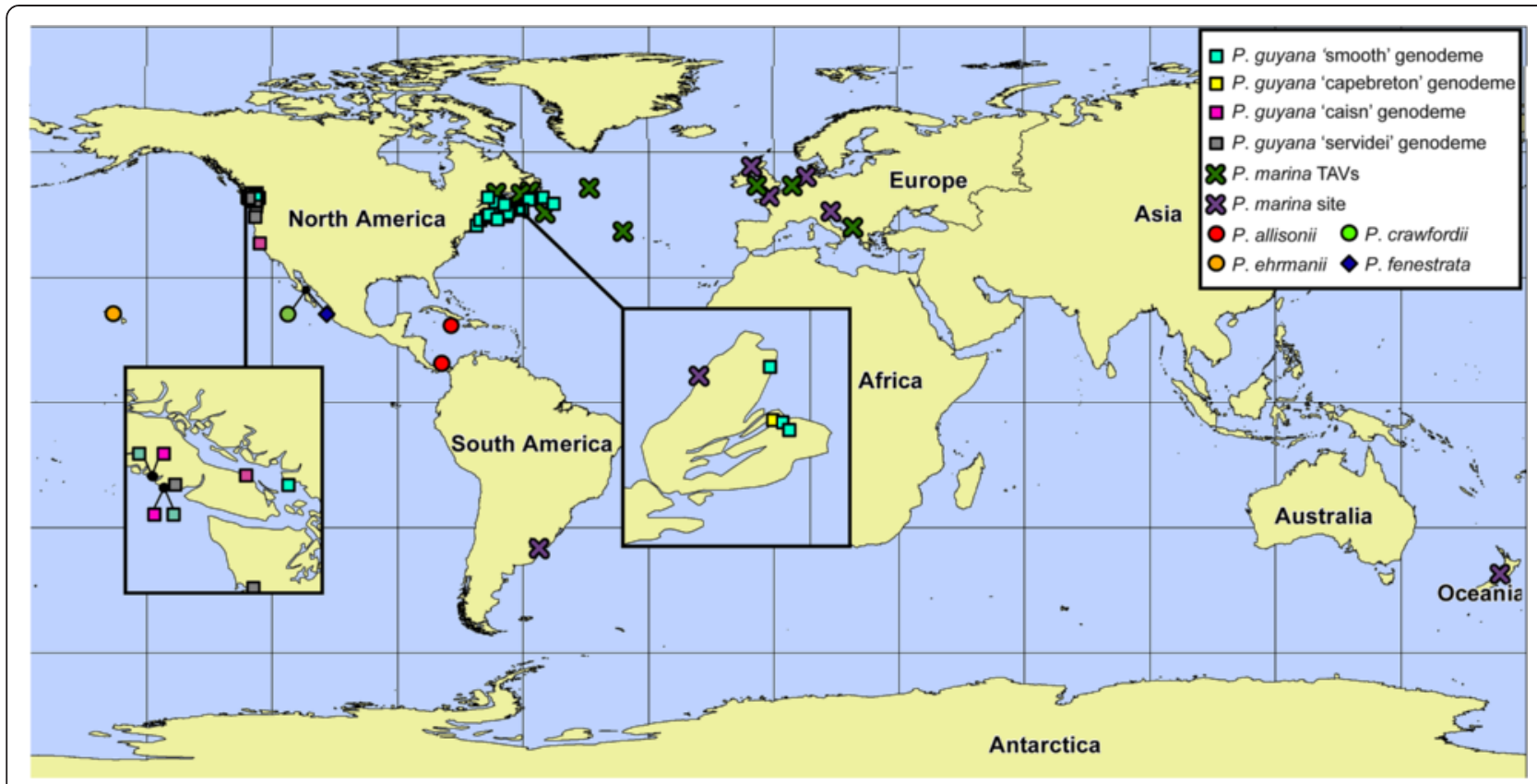

Figure 9 Distribution of Paralia species recovered in this study and in MacGillivary and Kaczmarska [6,10]. Inserts show hotspots of species richness. Leftmost is Vancouver Island, Canada and rightmost is Cape Breton Island, Canada. Leader lines to inserts emanate from original location on world map. P. marina, specimens collected from natural waters are denoted as 'site' while those collected on trans-Atlantic voyages are denoted as 'TAVs'.

P. marina clones and no signs of heteroplasmy among $P$. marina and $P$. guyana demes were found for any of the three sequence regions. The interspecific divergence in the conserved region of $18 \mathrm{~S}$ RNA gene fragment was $0-$ 7 bp (0-2\%). All P. guyana genodemes were $100 \%$ identical in the $18 \mathrm{~S}$ segment but all were $2 \%$ divergent from $P$. marina. Interspecifically, there were $0-30$ bp (0-6\%) differences in the $r b c \mathrm{~L}$ fragments, depending on the genodeme. The 'capebreton' and 'servidei' genodemes of $P$. guyana showed $100 \%$ identity while $P$. marina and the three prickly genodemes of $P$. guyana had the highest divergence (Additional file 1).

For the ITS region, the lowest sequence divergence occurred between the Pacific 'caisn' and Atlantic 'capebreton' genodemes of $P$. guyana (2\%) whereas the highest occurred between the P. guyana 'smooth' genodeme and $P$. marina (36\%). ITS1 sequence divergences were between 10-113 bp (2-34\%) for the P. guyana 'caisn' and $P$. guyana 'servidei' genodemes (both from the Pacific coast) and the 'smooth' genodeme of $P$. guyana and $P$. marina, respectively. The 'servidei' and 'caisn' genodemes of P. guyana shared $100 \%$ identity in the $5.8 \mathrm{~S}$ gene sequence, whereas the 'capebreton' genodeme of $P$. guyana and $P$. marina were the most diverse; $9 \mathrm{bp}$ or $5 \%$. The ITS2 marker was the most divergent sequence region examined. The P. guyana 'smooth' and 'caisn' genodemes were the most similar (4 bp or $1 \%$ ) and $P$. marina and the P. guyana 'servidei' genodeme were the most diverse (138 bp or 58\%). For the $5.8 \mathrm{~S}+\mathrm{ITS} 2$ barcode region sensu $[47,48]$ the sequence divergences ranged from $1 \%$ between the 'smooth' and the 'caisn' genodemes of $P$. guyana to $25 \%$ between $P$. marina and the 'capebreton' and 'caisn' genodemes of P. guyana.

\section{ITS2 secondary structures}

Folding of ITS2 rRNA transcripts revealed two very different secondary structures in Paralia marina and $P$. guyana with five helices in the former and four in the latter (Figures 11 and 12). Nonetheless, they both demonstrated the hallmarks of ITS2 structures seen in many eukaryotes such as Helix II being relatively short and harbouring a pyrimidine-pyrimidine mismatch; here different for each species with C:U in P. marina and U:C and $\mathrm{C}: \mathrm{C}$ in $P$. guyana (depending on genodeme, arrowheads in Figures 11 and 12). Helix III was the longest and carried known variants of the ultra-conserved motif at the distal end of the $5^{\prime}$ side of the Helix (UGGU for P. marina and AGGA for P. guyana, surrounded by ellipses in Figures 11 and 12). These two Paralia species also showed other, albeit very few, areas of conservation (boxes in Figures 11 and 12). These included: (1) a six nucleotide sequence which preceded Helix I, (2) five basal pairs of Helix I, (3) part of the spacer between Helix I and Helix II, (4) two basal pairs of Helix II, (5) two base pairs near the terminal loop in Helix II, (6) two base pairs near the base of Helix III, (7) a base pair 


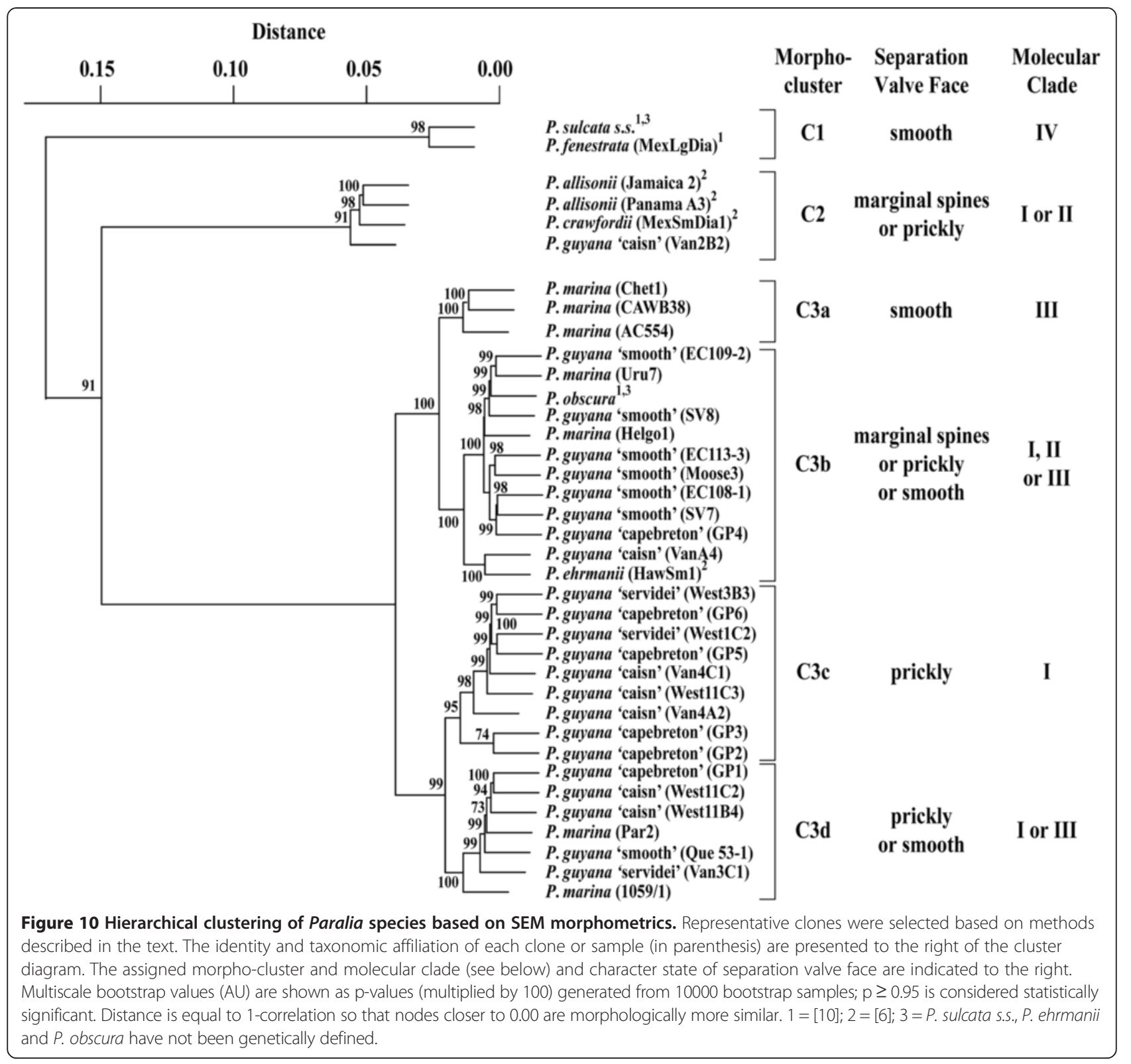

immediately below the super-conserved motif in Helix III, and (8) the basal part of Helix IV which contained three base pairs. Some of these areas were also conserved between the two species discussed here and species in the P. longispina species-complex [6] and some other algae $[49,50]$.

\section{Relationship between the taxa examined}

The overall topologies of the trees inferred from all the analyses (ML, MP and NJ) were similar for the 18S, ITS, concatenated nuclear $18 \mathrm{~S}+5.8 \mathrm{~S}+\mathrm{ITS} 2$ and $r b c \mathrm{~L}$ marker phylogenies. Consequently, we present only the concatenated nuclear encoded (Figure 13) and plastidal $r b c \mathrm{~L}$ trees (Figure 14). In the phylogenetic analysis of $18 \mathrm{~S}+$
$5.8 \mathrm{~S}+\mathrm{ITS} 2$ three major clades were recovered with similar morphological separation as that found in the $r b c \mathrm{~L}$ (containing larger number of species). The $P$. guyana clade (clade I) received stronger bootstrap support in $18 \mathrm{~S}+5.8 \mathrm{~S}+\operatorname{ITS} 2(92 / 88 / 100 \%$, Figure 13$)$ than in the $r b c \mathrm{~L}$ tree $(78 / 52 / 75 \%$, Figure 14). Each genodeme of $P$. guyana occupied its own terminal branch in the $18 \mathrm{~S}+$ $5.8 \mathrm{~S}+\mathrm{ITS} 2(>89 \%)$ tree whereas in the $r b c \mathrm{~L}$ tree, the $P$. guyana 'smooth' genodeme and the three prickly genodemes of $P$. guyana formed common terminal groups $(>92 \%)$. Support was similar for clade II in the concatenated rDNA (94/91/100\%) and $r b c \mathrm{~L}$ (96/99/95\%) trees. For clade III, comprised of P. marina, similar support was shown in the $18 \mathrm{~S}+5.8 \mathrm{~S}+\mathrm{ITS} 2$ and $r b c \mathrm{~L}$ trees 


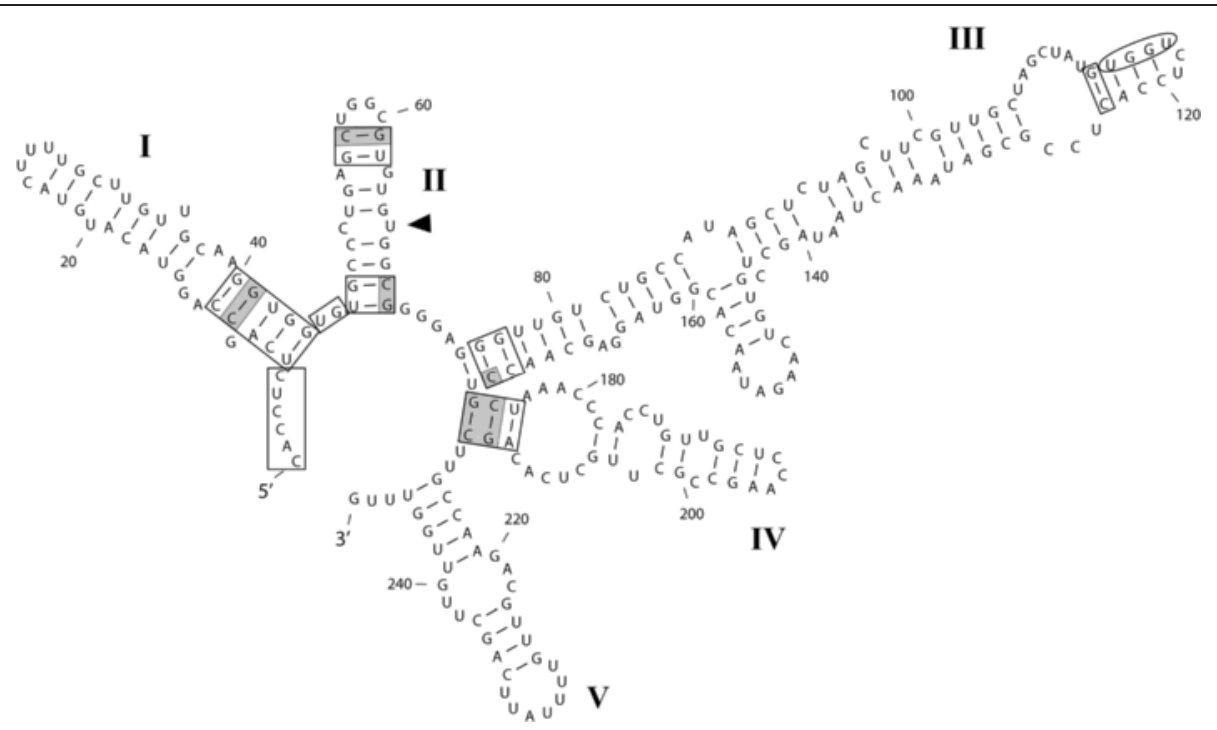

Figure 11 ITS2 rRNA transcript secondary structure model of Paralia marina (strain Helgo3). Sequence orientation (5' to $3^{\prime}$ ) and helix numbering (I, II, III, IV and V) are specified. An arrowhead shows the pyrimidine-pyrimidine mismatch (CXU) on Helix II, the ultra-conserved UGGU motif on the $5^{\prime}$ side of Helix III is indicated by an ellipse and areas of relative conservation between P. marina and P. guyana are boxed. CBCS between $P$. guyana and P. marina are shaded gray across the entire base pair. HCBCs between P. guyana and P. marina are shaded only on the changed base of the base pair.

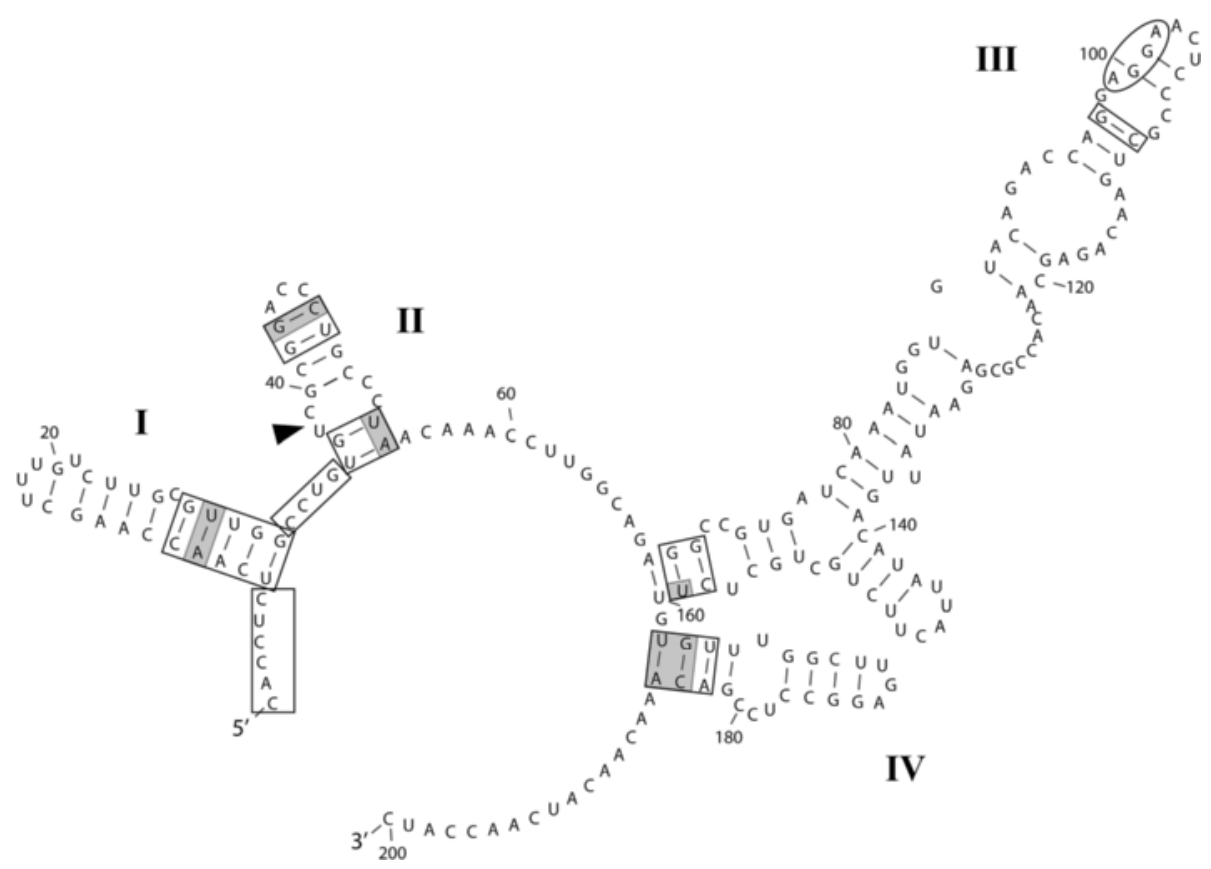

Figure 12 ITS2 rRNA transcript secondary structure model of Paralia guyana (strain SV7). Sequence orientation (5' to $3^{\prime}$ ) and helix numbering (I, II, III and IV) are specified. An arrowhead shows the pyrimidine-pyrimidine mismatch (C:U and C:C) of Helix II, the known variant of ultra-conserved AGGA motif on the $5^{\prime}$ side of Helix III is indicated by an ellipse and areas of relative conservation between $P$. marina and $P$. guyana are boxed. CBCs between P. guyana and P. marina are shaded gray across the entire base pair. HCBCs between P. guyana and P. marina are shaded only on the changed base of the base pair. 


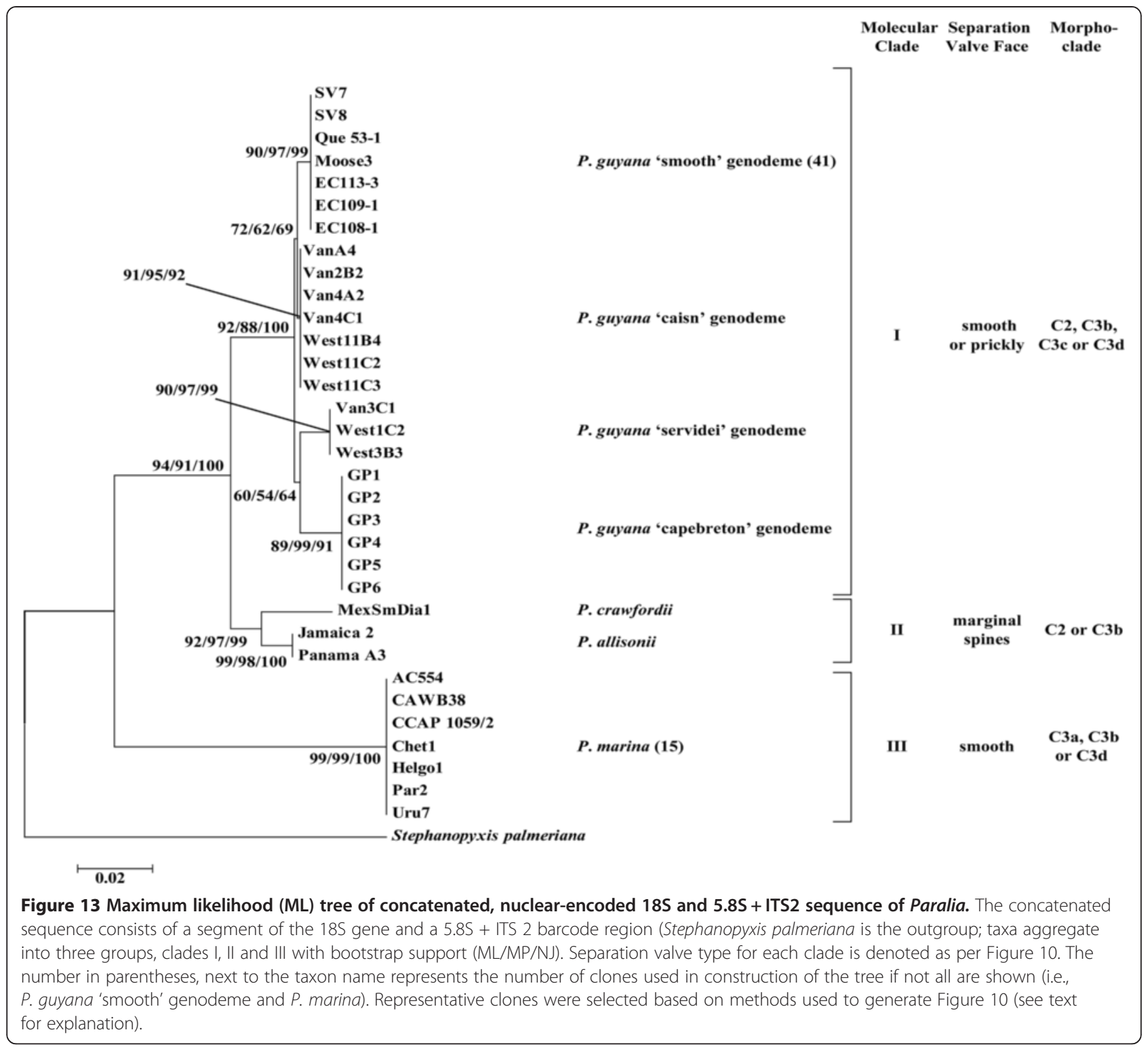

(>97\%). Paralia allisonii and P. crawfordii occupied terminal branches in clade II and had high support in both the concatenated $(>92 \%)$ and $r b c \mathrm{~L}(>98 \%)$ trees. The $18 \mathrm{~S}+5.8 \mathrm{~S}+\mathrm{ITS} 2$ sequence for $P$. fenestrata could not be obtained from the few single chains available; these chains were also uncultivable and so this species is absent from the concatenated tree. Nonetheless, P. fenestrata occupied a terminal branch in the $r b c \mathrm{~L}$ tree and received poor to strong support (90/60/89\%, Figure 14), depending on the analysis.

\section{Discussion}

\section{Segregation of taxa}

The intercalary valves of the two newly circumscribed taxa (Paralia marina, P. guyana) and four genodemes of P. guyana ('smooth', 'caisn', 'capebreton' and 'servidei') were metrically inseparable irrespective of the microscopical methods applied (Table 2). This was well reflected in the results of hierarchical clustering where $P$. marina and all genodemes of $P$. guyana were intermixed in Clade 3. Interestingly, this approach successfully segregates Paralia longispina-like species [6]. The external surface structures of separation valves in $P$. guyana s.l. set some, but not all these entities apart. Paralia marina and the 'smooth' genodeme of $P$. guyana were morphologically cryptic, both in intercalary valve morphometrics and in having smooth separation valve faces. Similar in size, small-diameter separation valves of P. sulcata s.s. (when/if such are discovered), may also fall into this category. On the other hand, the three other genodemes of P. guyana ('caisn', 'capebreton' and 'servidei') carried prickles or stout spines of various size and 


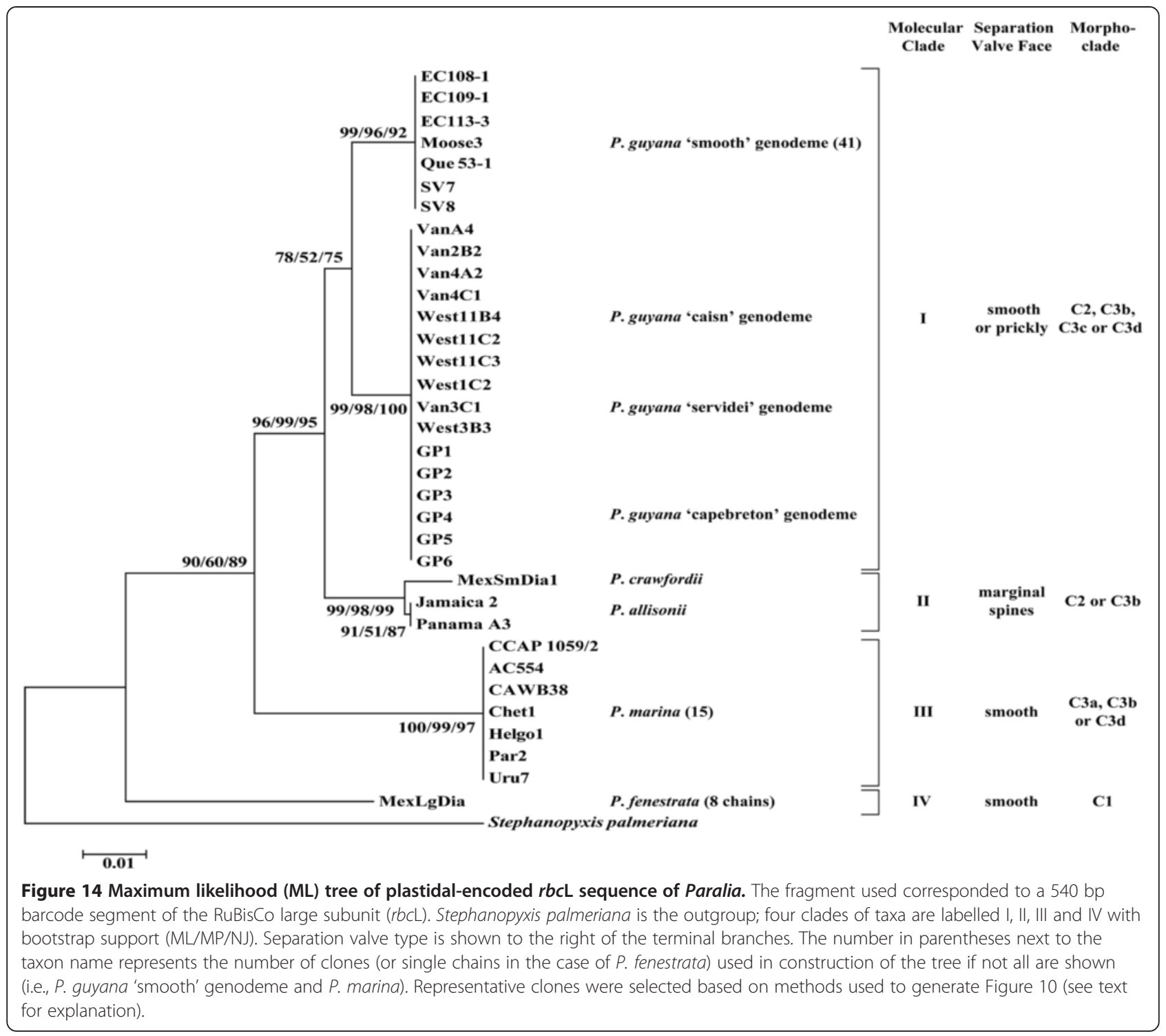

abundance on separation valves, but these were only visible on SEM images.

In contrast to morphology, all $P$. guyana demes were genetically distinct from each other and from $P$. marina, but divergence level varied depending on the marker. Not surprisingly, the sequence region with the least divergence was the conservative 373-bp fragment of the $18 \mathrm{~S}$ gene; all genodemes of $P$. guyana diverged from $P$. marina by $\mathrm{d}=0.02$. This is twice as much as morphologically distinct $P$. allisonii and $P$. crawfordii, who differ by only 2-bp (or $\mathrm{d}=0.01$, [6]). In comparison, several morphologically distinct species of Aulacoseira Thwaites, the only other genus of the non-polar centrics (Coscinodiscophyceae, [51]) where congeneric sequence data are available for comparison, yield uncorrected ddistances between the species of only 0.01 [52]. In raphid pennate diatoms, such as reproductively isolated species of Sellaphora Mereschowsky, sequence divergence in this region is even smaller $(\mathrm{d}=0.005)$, supporting our conclusion that $P$. marina and $P$. guyana are separate species. All genodemes of P. guyana showed 100\% sequence identity in this gene region.

More divergent sequences were recovered from the $5.8 \mathrm{~S}+$ ITS2 barcode fragment sensu $[47,48]$ and in the equally tested fragment of $r b c \mathrm{~L}$ sensu [53] where the inter-/intraspecific guidance thresholds are proposed at $\mathrm{d}=0.07$ and $\mathrm{d}=0.01$, respectively, for polar diatoms (centric and pennates); comparisons for non-polar Coscinodiscophycean species are unavailable. Compared to these thresholds, $P$. marina was very distant from $P$. guyana ( $\mathrm{d}>0.24$ for $5.8 \mathrm{~S}+\mathrm{ITS} 2$; $\mathrm{d}>0.05$ for $r b c \mathrm{~L}$ ). The divergence level between the genodemes of $P$. guyana fell within intraspecific thresholds for the $5.8 \mathrm{~S}+\mathrm{ITS} 2$ $(\mathrm{d}<0.04)$. For the $r b c \mathrm{~L}$ fragment, comparisons between 
the 'caisn' and 'smooth' genodemes and the 'capebreton' and 'servidei' genodemes of P. guyana fell within proposed intraspecific thresholds $(d=0.01$ and $d=0.00$, respectively), whereas the 'capebreton' and 'servidei' genodemes both diverged from the 'caisn' and 'smooth' genodemes by $\mathrm{d}=0.02$ which is greater than the proposed intraspecific threshold $(\mathrm{d}=0.01)$. However, MacGillivary \& Kaczmarska [6] demonstrated the polar centric DNA barcode threshold for the $r b c \mathrm{~L}$ fragment of $\mathrm{d}=0.01$ was not infallible as it only pooled $81 \%$ of intraspecific sequences compared. Furthermore, the intra-/interspecific $r b c \mathrm{~L}$ DNA barcode threshold may differ between families and even genera ([6], Table 2), reflecting their own rates of evolution.

The secondary structure of the ITS2 transcript was used here as a proxy for reproductive isolation [54-56] or lack thereof [57]. This approach has already been successfully applied to cryptic and semi-cryptic diatom species complexes among raphid e.g., $[4,58,59]$ and araphid pennates [8] and non-polar centrics [6]. The ITS2 secondary structure of $P$. marina (Figure 11) was clearly structurally distinct from $P$. guyana (Figure 12), P. allisonii and $P$. crawfordii (figure 45 in [6]); the former had five helices and the latter three species had four and only very few areas of conservation on the four common helices. This is similar to the case of some species of Sellaphora [60] where even in relatively closely related congeners sequence alignment of the ITS region is a challenging task. Between-species comparisons of ITS2 secondary structures, following the phylogenetic approach of Caisová et al. $[49,50]$ also revealed indels and mutations. The most unanticipated intragenerically were mutations in the YGGY super-conserved motif on the 5' side of Helix III; UGGU in P. marina, AGGU in P. allisonii and P. crawfordii and AGGA in $P$. guyana, thus far unprecedented among diatoms.

Coleman [55] demonstrated that the presence of even one $\mathrm{CBC}$ in conserved regions of Helix II and Helix III coincided with sexual incompatibility between various species of Volvocales. This is also likely true for other green algal orders, albeit mating data are more limited for them, as is the case for a number of algal taxa in general. In Ulvales [49], Chaetophorales, Oedogoniales and some Sphaeropleales [50] CBCs were most commonly found on deeper (not terminal) branches of their phylogenetic trees. In these positions, the $\mathrm{CBCs}$ correspond to species-complexes, genera or even higher taxonomic ranks $[49,50]$ rather than species and thus, support the assumption of genetic isolation between members of different $\mathrm{CBC}$-clades is even stronger. Therefore, clear structural differences between the ITS2 secondary structures of all helices in the species discussed here support our conclusion that they represent separate species.

\section{Comparison to other morpho-species of Paralia}

The P. guyana 'caisn', 'capebreton' and 'servidei' genodemes are the first Paralia specimens to demonstrate prickles on the separation valve face. Protrusions on the separation valve face are also present in extinct $P$. siberica (Schmidt) Crawford and Sims, but are more pronounced and roundended [11]. Additionally, the marginal linking spines are much more robust in $P$. siberica than in the prickly genodemes of $P$. guyana and consist of double spines [11] rather than the single spines present in $P$. guyana.

In contrast to the prickly separation valve faces in the three genodemes of $P$. guyana presented here, the smooth separation valve face, such as in $P$. marina and the $P$. guyana 'smooth' genodeme is the most commonly reported morphotype in the literature in both contemporary and fossil samples. For example, P. sulcata s.l. valves from natural samples presented in [15] and [12], from Plymouth, UK and various sites near Japan are morphologically inseparable from $P$. marina and from the $P$. guyana 'smooth' genodeme in 10 metric characters we examined. Similarly, a recently described Miocene morphospecies, P. obscura, found to co-occur with $P$. sulcata s.s. in Ehrenberg's [16] original material from Oran [10] cannot be set apart from the two taxa examined here. Such a degree of morphological similarity between species, some geologically separated by $\sim 20$ MY (i.e., $P$. obscura, P. marina and the P. guyana 'smooth' genodeme), has led to nomenclatural and identification challenges. This must have and will likely continue to lead to ecological incongruities (discussed below) when species recognition is based exclusively on morphological characters on the intercalary valves in particular. Our results, therefore, illustrate the usefulness of molecular tools in Paralia taxonomy, especially in recognising the 'smooth' morphotype. The level of sequence divergence in ITS2 found between $P$. marina and the P. guyana 'smooth' genodeme, uncommon among diatom congeners thus far examined, suggests the significant potential for the existence of other undiscovered, morphologically cryptic species in this complex.

\section{Taxonomic implications for ecology}

Paralia sulcata s.l. is commonly reported worldwide and from a wide range of environments. Morphologically cryptic and semi-cryptic diversity discovered here within this "species" may help to reconcile conflicting reports of $P$. sulcata s.l. ecology. For example, studies have shown that some populations of P. sulcata s.l. have competitive advantage and thrive under low light conditions [61-63], but other reports have indicated others who have an advantage when irradiance levels are high, such as during bright winter days [64]. Interestingly, the studies by Margalef [61], Zong [62] and McQuoid \& Nordberg [63], all occur in Europe and the Hobson \& McQuoid 
[64] work involved Paralia sulcata s.l. populations from British Columbia, Canada. Our data suggest that these two sets of studies may have been in fact conducted on two different species of Paralia. The species of Paralia we reported from western Canada were not found (in our study) in Europe and vice versa. A similar case may be made for nitrogen optima as McQuoid \& Nordberg [63] noted that relative abundance of $P$. sulcata s.l. among surface sediments in western Sweden is positively correlated with the degree of mixing in the water column, but negatively correlated with higher seawater nitrogen concentrations. Conversely, Liu et al. [65] found greater abundance of P. sulcata s.l. in waters which are richer in nitrogen. Since the study by McQuoid \& Nordberg [63] was conducted in Sweden (Atlantic Ocean) and the study by Liu et al. [65] occurred in the South China Sea (Pacific), those studies may have also been, in fact, carried out on two discrete, physiologically different species of Paralia. As our data illustrate, the availability of globally consistent tools to recognise investigated species (when valve morphology may be insufficiently differentiated) is a necessary prerequisite to better understand the autoecology, including biogeography, of diatoms.

\section{Biogeography}

Undoubtedly, the genus Paralia Heiberg is cosmopolitan. However, some species complexes within this genus may not be. For example, based on what is known about their distribution to date, the morphologically distinct $P$. longispina-like species and specimens (see [6]) were all thus far recovered from subtropical and tropical locations between $17^{\circ} 50^{\prime} \mathrm{S}$ (Viti Levu, Fiji) and $26^{\circ} 38^{\prime} \mathrm{N}$ (Haha-jima, Japan); none were recovered from temperate, shallow coastal waters of North America despite extensive sampling. Conversely, $P$. guyana and $P$. marina were recovered only from more temperate and eutrophic waters. Paralia guyana was found on both the Atlantic and Pacific coasts of North America; its distribution ranged as far north as Botwood, Canada $\left(49^{\circ} 08^{\prime} \mathrm{N}\right)$ and as far south as Marshall, USA $\left(38^{\circ} 09^{\prime} \mathrm{N}\right)$. Samples from both the east and west coasts of Canada contained the 'smooth' genodeme of $P$. guyana whereas the prickly genodemes had a more restricted distribution with one genodeme, 'capebreton', found at only one site (Grove's Point, Nova Scotia), despite intensive sampling of the Canadian Maritimes. In contrast, Paralia marina had a much wider distribution as it was recovered from the European Atlantic, and single sites in Uruguay, New Zealand, and eastern Canada. Similar types of intrageneric distribution, with some taxa being restricted while others cosmopolitan, may be found, for example, among Navicula Bory de Saint-Vincent [4] or Asterionellopsis Round [8]. These and our work may represent a distribution pattern that will be seen more commonly [9] as the application of molecular methods in diatom taxonomy and consequently in ecology (e.g., using high throughput sequencing) becomes more frequent. For such studies molecular delineation of diatom species is of great significance.

Although $P$. marina specimens examined were widely distributed, sequences of all three markers examined in this study ( $r b c \mathrm{~L}, 18 \mathrm{~S}$ and ITS) show 100\% identity. The maintenance of such a degree of sequence identity by benthic diatom populations from oceans worldwide may be due, at least in part, to its capacity to survive transoceanic voyages in ship ballast waters and sediments. Chains of Paralia were reported from nearly every ship ballast examined e.g., [23-25]. Paralia species have demonstrated the ability to survive weeks in ship ballast tanks; both in the water column (up to 14 days in this study and 33 days elsewhere [24]) and possibly even longer in ship ballast sediments [36]. Therefore, shipmediated dispersal may contribute to the capacity of some Paralia species (exemplified by P. marina) to cross their natural barriers and maintain genetic homogeneity worldwide.

\section{Paralia in TAVs}

Paralia marina was the only representative of the genus recovered from ship ballast tanks from the transAtlantic voyages examined here and comprised $96 \%$ of the cells recovered from the three TAVs. Additionally, $P$. marina cell concentrations at the end of each voyage, and after mid-ocean ballast water exchange, ranged from

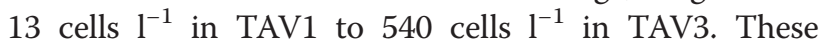
quantities were comparable to those reported from Pacific crossings for P. sulcata s.l. by Klein et al. ([24]; 5-28 cells $\mathrm{I}^{-1}$ ) and Dickman \& Zhang ([21]; 5-40 cells $\left.\mathrm{I}^{-1} \mathrm{~L}\right]$. Paralia marina cell concentrations at the end of TAV3 were the second highest cited in the literature to date, next to Paralia specimens enumerated in Ruiz \& Smith ([66]; 18000 cells $\mathrm{l}^{-1}$ ). Given the known tank volume, the average Paralia marina specific propagule size in one ballast tank at the end of each of the three TAVs would be $\bar{x}=130592$ cells. If the $5.47 \times 10^{9}$ litres of ballast water arriving in eastern Canada from Europe in 2006-2007 [67] is a typical annual volume arriving and in position to legally deballast, the number of cells of $P$. marina these ships carry per year may be estimated at $7.14 \times 10^{14}$ cells. This is a large propagule size, particularly when de-ballasting concentrates in just a few ports (or areas) and continues for decades as it has in Atlantic Canada. Thus, it is unanticipated to discover P. marina in only one site in eastern Canada (Cheticamp, Nova Scotia) despite extensive sampling for Paralia throughout the region. Lockwood et al. [34] and Simberloff [35] argued that a large propagule size and multiple propagule introductions are two of the best predictors of the successful establishment of 
a species in a non-native territory, but of course other factors may interfere. However, the same conditions do not generally correlate with secondary dispersal from the site of primary establishment. It therefore would be worthwhile to conduct an additional survey to determine if the species has spread since our collection in 2009.

Secondary dispersal, involves other factors (natural and/or anthropogenic), as evidenced by numerous examples of failed intentional introductions [68-70]. Some of these factors may involve suboptimal physico-chemical conditions in the species' non-native environment; e.g., temperature, salinity and nutrients. These might play, at least in part, a role in the case for P. marina de-ballasted in eastern Canadian waters. The physico-chemical regimes present on the Canadian side of the Atlantic may be sufficiently fitting to sustain, but not to expand $P$. marina populations. For example, Gebühr et al. [71] investigated the seasonality of P. marina (clones Helgo1, Helgo2, Helgo3, Helgo4; reported as P. sulcata in [71]) and found that temperature, light and nutrient conditions were the environmental factors with the strongest effect on their abundance. Furthermore, although similar in some properties, the coastal waters of the European and Canadian Atlantic differ in a number of specific physico-chemical characters with Europe having, for example, generally greater annual average sea-surface temperatures [72], salinities [73], nutrient (e.g., nitrogen and silica, [74]) and dissolved oxygen [75] concentrations. This does not mean that $P$. marina may not ever establish a stronger presence in eastern Canadian waters in the future if strong propagule pressure continues. In some cases a long lag time exists between species introduction and species establishment $[76,77]$ and longer still before the species expands beyond its original establishment site. In addition, species which have been outside their physico-chemical optima may become capable of establishing pioneer populations in nonnative habitats because of favourable changes brought on by global climate change or by favourable mutations in the founder population [35].

\section{Conclusions}

Examination of the taxa presented here and earlier $[6,10,12]$ shows the existence of three morphotypes defined by their separation valve face morphology. The $P$. longispina group (P. allisonii, $P$. crawfordii, $P$. ehrmanii and $P$. longispina) has marginal triangular spines on separation valves. The $P$. guyana (genodemes 'caisn', 'capebreton' and 'servidei') which often have prickles on the separation valve face constitute a second group. The $P$. marina group ( $P$. marina, the 'smooth' genodeme of $P$. guyana, $P$. obscura, $P$. sulcata s.s. and $P$. fenestrata) has smooth separation valve faces. This latter group may be further subdivided into $P$. sulcata-like species $(P$. sulcata s.s. and $P$. fenestrata) with pronounced fenestrae and $P$. marina, $P$. guyana 'smooth' and $P$. obscura, with subtle fenestrae often overlaid by a siliceous lid, thus obscured in SEM (examining the valve surface), but visible in the light (transmitting) microscope. Each of these groups consists of multiple, generally morphologically semi-cryptic or cryptic species.

Genetic delineation, on the other hand, segregates all these species and their demes readily. Correct identification of species is at the heart of species and community ecology, including non-indigenous introductions. We demonstrated that despite the long and strong propagule pressure of $P$. marina arriving in transoceanic ship ballast tank waters from European sites, it was only found in one site in Eastern Canada in 2009. We also demonstrated that ship ballast sediments arriving to Eastern Canadian ports from intercoastal locations contain live Paralia chains, which, when rejuvenated in laboratory cultures all proved to be the 'smooth' genodeme of $P$. guyana. We also demonstrated that all specimens of Paralia arriving at Canadian coasts in ballast of transAtlantic vessels examined are $P$. marina. This suggests that dispersal opportunity is not the barrier for $P$. marina for establishing stronger presence on the Atlantic coast of Canada. Because the two species specimens are cryptic and semi-cryptic, we thus advocate for the wide use of molecular means of species recognition in monitoring the establishment and further, secondary dispersal of Paralia species outside their native geographical ranges. This is of particular significance in eastern Canada where the propagule pressure of $P$. marina continues and the change in the local environment, man-mediated or otherwise, may facilitate the permanent colonization of this diatom in this region.

\section{Methods}

\section{Establishment of monoclonal cultures}

Seawater and sediment samples were collected from 45 inter- and subtidal sites and from ship ballast sediments; five in Europe, one in New Zealand, one in Uruguay and 38 from the Atlantic (including 15 ship ballast sediments) and Pacific coasts of North America. Only the last port of call is identified for ballast sediments (Table 1 and discussed detail in Villac \& Kaczmarska [36] and Villac et al. [25]). A total of 184 clones were initially established as described in MacGillivary \& Kaczmarska [6]. These were screened morphologically and genetically; the widest range of cell diameter and $100 \%$ identity in genetic markers were criteria for selection of the final set of 76 monoclonal cultures included in detailed analyses (Table 1). All culture isolates were grown in $\mathrm{f} / 2$ media at $20^{\circ} \mathrm{C}$ at an irradiance of $40-50 \mu \mathrm{mol} \mathrm{m}{ }^{-2} \mathrm{~s}^{-1}$, to facilitate a "common garden" experimental condition with the aim to emphasise genetic (in contrast to specific for individual local environmental) aspects of frustule morphology. 


\section{Ballast water on board processing, cell counts and molecular identification}

In addition, ballast water was sampled from ships during three trans-Atlantic voyages (TAVs). TAV1 (October 1524, 2008) and TAV2 (November 15-24, 2008) crossed from Rotterdam, Netherlands to Sept-Îles, Quebec, Canada. TAV3, from September 16-October 2, 2009, originated in Bar, Montenegro and ended in Havre-Saint-Pierre, Quebec, Canada. One ballast tank on each ship was sampled at the beginning and the end of the voyage, and at least once during the crossing. Sampling protocol and diatom enumeration in the samples from the three TAVs followed Klein et al. [24] except here the entire contents of the 3-8 L of collected ballast water sample was filtered, settled and examined due to the exceptionally low abundance of diatoms in these samples. Diatoms from TAVs 1, 2 and 3 were counted from tank $5 \mathrm{~S}, 7 \mathrm{~S}$ and $6 \mathrm{P}(\mathrm{S}=$ starboard and $\mathrm{P}=$ port), respectively on voyage day 9,8 and 14 , respectively. Cells were considered live at the time of collection and only counted when intact chloroplasts autofluoresced. Following cell counts, the ITS region of 18 Paralia chains were amplified following [78] with the following exceptions: immediately after isolation into PCR tubes, cells were subjected to three freeze/thaw cycles at temperatures of $+/-80^{\circ} \mathrm{C}$ to break heavily silicified frustules and liberate DNA and the annealing temperature of primers in the PCR cycle was adjusted to $50^{\circ} \mathrm{C}$.

\section{DNA extraction, amplification and sequencing}

DNA of cultured cells was extracted from frozen Paralia pellets harvested in mid-exponential growth phase using an UltraClean Soil DNA Kit (MoBio Laboratories, Carlsbad, CA, USA) following manufacturer's recommendations. Three different sequence regions were amplified. From nuclear ribosomal RNA, a portion of the small subunit (18S) region (373 bp long, $195 \mathrm{bp}$ downstream from the start codon) and a 682-711 bp internal transcribed spacer (ITS) region were amplified using primers $18 \mathrm{sF}$ and $18 \mathrm{sR}$ [79] and ITS1 and ITS4 [80] and Paralia-specific primers designed for this study: ParFOR1 (5'-GCCTGTGAAAT AGCCTCCT-3'), ParFOR2 (5'-CCGACAATAGGGTGACCTG-3'), ParREV1 (5'-GCGGGTATTCTTACTTAACT TG-3') and ParREV2 (5'-CCGGACTC AAACCAACAA G-3'), respectively. The fragment (540 bp long, 417 bp from the start codon) of the plastidal-encoded large subunit of Rubisco ( $r b c \mathrm{~L})$ was amplified using primers DtrbcL2R ([81]; as NDrbcL8) and DtrbcL2F, DtrbcL3F and DtrbcL3R [78]. The sequence regions targeted were amplified and sequenced following MacGillivary \& Kaczmarska $[6,53]$ and edited and aligned with BioEdit version 7.0.5.3 [82] and Clustal W version 1.4 [83]. The ITS2 portion of the ITS region was aligned between taxa with the aid of ITS2 secondary structures.

\section{Sequence analysis}

Molecular grouping of clones into respective species and genodemes was demonstrated in the form of trees. These were constructed from a concatenated sequence consisting of the nuclear 18S rRNA fragment and the $5.8 \mathrm{~S}+\mathrm{ITS} 2$ barcode $[47,48]$ and from a $r b c \mathrm{~L}$ sequence representing a supplemental DNA barcode for diatoms [53]. All trees were constructed using MEGA version 5.03 [84]. Distance (neighbour-joining, NJ) trees were inferred from the pairwise Kimura-2-Parameter (K2P) model. Maximum parsimony (MP) trees were generated by close-neighbour-interchange $(\mathrm{CNI})$ on random trees. For Maximum Likelihood (ML) trees, jModeltest version 0.1.1 [85] in Bosque [86] was used to select optimal base substitution models according to Akaike Information Criterion (AIC). The Hasegawa, Kishino and Yano $($ HKY $)+$ Gamma (G) model $(-\ln L=1033.68)$ and the Generalised time-reversible (GTR) $+\mathrm{G}(-\ln \mathrm{L}=1531.00)$ were the most optimal for the nuclear and the $r b c \mathrm{~L}$ sequence fragments, respectively. Confidence of branching was calculated using 10000 bootstrap replicates for each tree. Clones included in both trees matched those included for HCA. Published sequences for members of the P. longispina species complex [6] and P. fenestrata (for $r b c \mathrm{~L}$ only) were also included in analyses (Table 1). Stephanopyxis palmeriana (Greville) Grunow was used as an outgroup for all trees, based on the close relationship between Paralia and Stephanopyxis in multigene phylogenies i.e., [87].

\section{ITS2 secondary structure analysis}

ITS2 secondary structure models were constructed using mfold version 2.3 ([88], http://mfold.rna.albany.edu/?q= mfold/RNA-Folding-Form2.3) using default parameters except for temperature, which was set to $20^{\circ} \mathrm{C}$ to reflect the culture growth environment. Structures were drawn using VARNA 3.1 ([89], http://varna.lri.fr). Helices were labelled according to Mai \& Coleman [90]. Specific structures were compared following the phylogenetic approach of Caisová et al. [49,50].

\section{Acquisition and analysis of morphometric data}

At least 10 randomly-encountered, cleaned valves from each of the monoclonal cultures were subjected to SEM-based ([91] or [92], as appropriate) morphometric analysis. The average of the metrics from each of 10 valve characters $(1-3,5,7-11$ in Figure 1 and pervalvar axis length, as in $[6,10,12,15])$ were used in a hierarchical clustering analysis (HCA). For this analysis, where genetically delineated taxa and genodemes (a group of conspecific individuals differing from others genetically [93]) were represented by eight or more clones (i.e., $P$. marina and $P$. guyana 'smooth' genodeme), numbers were randomly assigned to clones and a random number generator was 
used to select which seven clones would be included in HCA analysis. This was done to preserve figure clarity. HCA was performed using pvclust [94] running 10000 multiscale bootstraps and giving approximately unbiased $[95,96] p$-values of branch point probabilities in the dendrogram. Morphological terminology follows [6,10-12,15]; terms 'relief' and 'intaglio' refer to both external and internal linking spines in intercalary valves while only to internal linking spines in separation valves.

\section{Examination of preparation BM1021}

Valves of Paralia from W. Smith's preparation BM1021 from the Greville collection, British Natural History Museum, were examined using LM to better understand Smith's [17] original concept of Paralia marina (as Orthosira marina in that publication). Only the $40 \times$ objective could be used to examine these specimens because of the excessive thickness of the slide. Consequently, only the coarse and taxonomically non-informative morphological characters could be observed (i.e., diameter, fenestrae and marginal linking spines), but they were nonetheless considered in general comparisons. Un-mounted material from W. Smith's original gathering (if in existence) was not available to the authors.

\section{Accession numbers}

[GenBank: ITS: KP150089-KP150160, KP193457, JN201575, JN201577, JN201579; 18S: AY485227, KP149947-KP150016, JN201583, JN201585, JN201587; rbcL: KP150017-KP150088, KP253080, JN201591, JN201593, JN201595].

\section{Additional file}

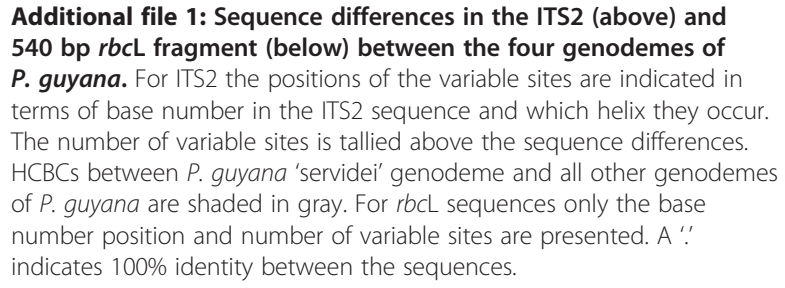

\section{Abbreviations}

AIC: Akaike information criterion; AU: Approximately unbiased; BGBM: Botanical gardens and botanical museum; BOLD: Barcode of life database; CBC: Compensatory base change; CCAP: Culture collection of algae and protozoa; CNI: Close-neighbour-interchange; G: Gamma; GTR: Generalised time-reversible; HCA: Hierarchical clustering analysis; HCBC: Hemi-Compensatory Base Change; HKY: Hasegawa, Kishino and Yano; ITS: Internal transcribed spacer; K2P: Kimura-2-parameter; ML: Maximum likelihood; MP: Maximum parsimony; NJ: Neighbour-joining; rbcL: RuBisCo large subunit; TAV: Trans-Atlantic voyage.
\end{abstract}

\section{Competing interests}

The authors declare that they have no competing interests.

\section{Authors' contributions}

Both authors contributed extensively to all aspects of the work presented in this paper. Both authors read and approved the final manuscript.

\section{Acknowledgements}

We are thankful for the cultures supplied by A. Beran (OGS/BIO Trieste), and C. Gebühr (AWI). R. Jahn kindly provided helpful guidance with regard to the Botanical Code. The samples, the source of the majority of our clones, were graciously collected by C. M. Archibald, J. M. Ehrman, G. Ferrari, members of the D. J. Hamilton lab (MTA), I. A. Luddington, A. M., M. A. and S. A. MacGillivary, L. A. Mather, F. G. Muise, U. Neumeier, K. Pauley, S. Roy, T. W. Therriault and M. C. Villac. We are grateful to CAISN personnel who coordinated and sampled ships on all trans-Atlantic voyages and in ports. We thank J. Wilbraham at the BNHM for help in obtaining slide BM1021, J. Carlton and two reviewers for helpful and formative comments on this manuscript. We appreciate SEM assistance, editorial comments, bioinformatics and statistical comments from J. M. Ehrman. Funding was provided by NSERC (Alexander Graham Bell CGS M to MLM and Discovery Grant to IK), the Canadian Aquatic Invasive Species Network (CAISN), and the Canadian Barcode of Life Network from Genome Canada through the Ontario Genomics Institute, NSERC, Mount Allison University and other sponsors listed at WWW.BOLNET.ca (to IK)

Received: 26 September 2014 Accepted: 20 January 2015

Published online: 15 February 2015

\section{References}

1. Créach V, Ernst A, Sabbe K, Vanelslander B, Vyverman W. Using quantitative PCR to determine the distribution of a semicryptic benthic diatom, Navicula phyllepta (Bacillariophyceae). J Phycol. 2006;42:1142-54.

2. Hernández-Becerril DU, Barón-Campis SA, Salazar-Paredes J, Alonso-Rodríguez R. Species of the planktonic diatom genus Skeletonema (Bacillariophyta) from the Mexican Pacific Ocean. Cryptogam Algol. 2013;34:77-87.

3. Sarno D, Kooistra WHCF, Medlin LK, Percopo I, Zingone A. Diversity in the genus Skeletonema (Bacillariophyceae). II. An assessment of the taxonomy of S. costatum-like species with the description of four new species. J Phycol. 2005;41:151-76

4. Poulícková A, Veselá J, Neustupa J, Skaloud P. Pseudocryptic diversity versus cosmopolitanism in diatoms: a case study on Navicula cryptocephala Kütz. (Bacillariophyceae) and morphologically similar taxa. Protist. 2010;161:353-69.

5. Lundholm N, Bates SS, Baugh KA, Bill BD, Connell LB, Léger C, et al. Cryptic and pseudo-cryptic diversity in diatoms - with descriptions of Pseudo-nitzschia hasleana sp. nov. and P. fryxelliana sp. nov. J Phycol. 2012:48:436-54.

6. MacGillivary ML, Kaczmarska I. Genetic differentiation within the Paralia longispina (Bacillariophyta) species complex. Botany. 2012;90:205-22.

7. Abarca N, Jahn R, Zimmermann J, Enke N. Does the cosmopolitan diatom Gomphonema parvulum (Kützing) Kützing have a biogeography? PLoS One. 2014:9:e86885.

8. Kaczmarska I, Mather L, Luddington IA, Muise F, Ehrman JM. Cryptic diversity in a cosmopolitan diatom known as Asterionellopsis glacialis (Fragilariaceae): Implications for ecology, biogeography, and taxonomy. Am J Bot. 2014;101:267-86.

9. Mann DG, Vanormelingen P. An inordinate fondness? The number, distributions, and origins of diatom species. J Eukaryot Microbiol. 2013;60:414-20.

10. MacGillivary ML, Kaczmarska I. Lectotypification of Paralia sulcata and description of P. obscura sp. nov. (Bacillariophyta) from the Ehrenberg Collection. Diatom Res. 2013;28:221-35.

11. Crawford RM, Sims PA, Hajós M. The morphology and taxonomy of the centric diatom genus Paralia. I. Paralia siberica comb. nov. Diatom Res. 1990;5:241-52.

12. Sawai $Y$, Nagumo T, Toyoda K. Three extant species of Paralia (Bacillariophyceae) along the coast of Japan. Phycologia. 2005;44:517-29.

13. Konno S, Jordan RW. Paralia longispina sp. nov., an extant species from Palau and Haha-jima, Western North Pacific. In: Likhoshway Y, editor. Proceedings of the Nineteenth International Diatom Symposium 19: 28 August - 3 September 2006; Listvyanka. Bristol: Biopress Ltd; 2008. p. 55-69.

14. Garcia M. Paralia elliptica sp. nov., an epipsammic diatom from Santa Catarina State, Brazil. Diatom Res. 2003;18:41-8.

15. Crawford RM. Taxonomy and frustular structure of the marine centric diatom Paralia sulcata. J Phycol. 1979;15:200-10.

16. Ehrenberg CG. Die Infusionsthierchen als vollkommene Organismen. Leipzig: Leopold Voss; 1838. 
17. Smith W. A Synopsis of the British Diatomaceae, vol. 2. London: J van Voorst; 1856.

18. Heiberg PAC. Conspectus criticus diatomacearum danicarum. Wilhelm Priors Forlag: Copenhagen; 1863.

19. Hallegraeff GM, Bolch CJ. Transport of diatom and dinoflagellate resting spores in ships' ballast water: implications for plankton biogeography and aquaculture. J Plankton Res. 1992;14:1067-84.

20. Subba Rao DV, Sprules WG, Locke A, Carlton JT. Exotic phytoplankton from ships' ballast waters: risks of potential spread to mariculture sites on Canada's East Coast. Can Data Rep Fish Aq Sci. 1994;937:1-51.

21. Dickman M, Zhang F. Mid-ocean exchange of container vessel ballast water. 2: Effects of vessel-type in the transport of diatoms and dinoflagellates from Manzanillo, Mexico to Hong Kong, China. Mar Ecol Prog Ser. 1999:176:253-62.

22. David M, Gollasch S, Cabrini M, Perkovič M, Bošnjak D, Virgilio D. Results from the first ballast water sampling study in the Mediterranean Sea - the Port of Koper study. Mar Poll Bull. 2007;54:53-65.

23. Chandrasekera WU, Fernando MAST. Accidental introduction of alien plankton into the Sri Lankan coastal zone through ballast water of cargo ships. Sri Lanka J Aquat Sci. 2009;14:87-103.

24. Klein G, MacIntosh K, Kaczmarska I, Ehrman JM. Diatom survivorship in ballast water during trans-Pacific crossings. Biol Invasions. 2010;12:1031-44

25. Villac MC, Kaczmarska I, Ehrman JM. The diversity of diatom assemblages in ships' ballast sediments: colonization and propagule pressure on Canadian ports. J Plankton Res. 2013;35:1267-82

26. Carlton JT. Transoceanic and interoceanic dispersal of coastal marine organisms: the biology of ballast water. Oceanogr Mar Biol Annu Rev. 1985;23:313-71.

27. Williams RJ, Griffiths FB, Van der Wal EJ, Kelly J. Cargo vessel ballast water as a vector for the transport of non-indigenous marine species. Estuar Coast Shelf S. 1988;26:409-20.

28. Drake JM, Lodge DM. Rate of species introductions in the Great Lakes via ships' ballast water and sediments. Can J Fish Aquat Sci. 2007;64:530-8.

29. Boalch GT, Harbour DS. Unusual diatom off the coast of south-west England and its effect on fishing. Nature. 1977;269:687-8.

30. Ostenfeld CH. On the immigration of Biddulphia sinensis Grev. and its occurrence in the North Sea during 1903-1907. In: Meddeleser fra Kommissionen for Havundersøgelser. Serie: Plankton, vol. 1. 1908. p. 1-44.

31. Kat M. Effects of fluctuating salinities on the development of Thalassiosira angstii, a diatom not observed before in the Dutch coastal area. J Mar Biol Assoc UK. 1982;62:483-4.

32. Endresen $\varnothing$, Behrens HL, Brynestad $S$, Andersen AB, Skjong R. Challenges in global ballast water management. Mar Pollut Bull. 2004;48:615-23.

33. Hulme PE. Trade, transport and trouble: managing invasive species pathways in an era of globalization. J Appl Ecol. 2009;46:10-8.

34. Lockwood JL, Cassey P, Blackburn TM. The more you introduce the more you get: the role of colonization pressure and propagule pressure in invasion ecology. Divers Distrib. 2009;15:904-10.

35. Simberloff $D$. The role of propagule pressure in biological invasions. Annu Rev Ecol Evol Syst. 2009;40:81-102.

36. Villac MC, Kaczmarska I. Estimating propagule pressure and viability of diatoms detected in ballast tank sediments of ships arriving at Canadian ports. Mar Ecol Prog Ser. 2011;425:47-61.

37. Lodge DM, Williams S, Maclsaac HJ, Hayes KR, Leung B, Reichard S, et al. Biological invasions: recommendations for US policy and management. Ecol Appl. 2006:16:2035-54

38. Sutherland WJ, Bailey MJ, Bainbridge IP, Brereton T, Dick JTA, Drewitt J, et al. Future novel threats and opportunities facing UK biodiversity identified by horizon scanning. J Appl Ecol. 2008;45:821-33.

39. Carlton JT. Biological invasions and cryptogenic species. Ecology. 1996;77:1653-5.

40. Carlton JT. The Scale and Ecological Consequences of Biological Invasions in The World's Oceans. In: Sandlund OT, Schei PJ, Viken A, editors. Invasive Species and Biodiversity Management. Dordrecht: Kluwer Academic Publishers; 1999. p. 195-212.

41. Geller JB, Darling JA, Carlton JT. Genetic perspectives on marine biological invasions. Ann Rev Mar Sci. 2010;2:367-93.

42. Huo $Y Y, X u X W$, Wang CS, Huang L, Wu G, Wu M. Detection of pathogenic Vibrio in the ballast water by polymerase chain reaction. J Zhejiang Univ (Sci Edit). 2010;37:330-4.
43. Briski E, Cristescu ME, Bailey SA, Maclsaac HJ. Use of DNA barcoding to detect invertebrate invasive species from diapausing eggs. Biol Invasions. 2011;13:1325-40.

44. Lang I, Kaczmarska I. Morphological and molecular identity of diatom cells retrieved from ship ballast tanks destined for Vancouver, Canada. Nova Hedwigia Beiheft. 2012;141:515-34.

45. McNeill J, Barrie FR, Buck WR, Demoulin V, Greuter DL, Hawksworth DL, et al. International code of nomenclature for algae, fungi, and plants (Melbourne Code) adopted by the Eighteenth International Botanical Congress Melbourne, Australia, July 2011. Regnum Vegetabile. 2012;154:1-240.

46. Jahn R, Kusber W-H. A key to diatom nomenclature. Diatom Res. 2009;24:101-11.

47. Moniz MBJ, Kaczmarska I. Barcoding diatoms: Is there a good marker? Mol Ecol Resour. 2009;9:65-74.

48. Moniz MBJ, Kaczmarska I. Barcoding of diatoms: nuclear encoded ITS revisited. Protist. 2010;161:7-34.

49. Caisová L, Marin B, Melkonian M. A close-up view on ITS2 evolution and speciation - a case study in the Ulvophyceae (Chlorophyta, Viridiplantae). BMC Evol Biol. 2011;11:262.

50. Caisová L, Marin B, Melkonian M. A consensus secondary structure of ITS2 in the Chlorophyta identified by phylogenetic reconstruction. Protist. 2013;164:482-96

51. Medlin LK, Kaczmarska I. Evolution of the diatoms: V. Morphological and cytological support for the major clades and a taxonomic revision. Phycologia. 2004;43:245-70.

52. Edgar SM, Theriot EC. Phylogeny of Aulacoseira (Bacillariophyta) based on molecules and morphology. J Phycol. 2004;40:772-88.

53. MacGillivary ML, Kaczmarska I. Survey of the efficacy of a short fragment of the rbcL gene as a supplemental DNA barcode for diatoms. J Eukaryot Microbiol. 2011;58:529-36.

54. Coleman AW. Paramecium aurelia revisited. J Eukaryot Microbiol. 2005;52:68-77.

55. Coleman AW. Pan-eukaryote ITS2 homologies revealed by RNA secondary structure. Nucleic Acids Res. 2007;35:3322-9.

56. Coleman AW. Is there a molecular key to the level of "biological species" in eukaryotes? A DNA guide. Mol Phylogenet Evol. 2009;50:197-203.

57. Kremp A, Tahvanainen P, Litaker W, Krock B, Suikkanen S, Leaw CP, et al. Phylogenetic relationships, morphological variation and toxin patterns in the Alexandrium ostenfeldii (Dinophyceae) complex: implications for species boundaries and identities. J Phycol. 2014;50:81-100.

58. Amato A, Kooistra WHCF, Levialdi Ghiron JH, Mann DG, Pröschold T, Montresor M. Reproductive isolation among sympatric cryptic species in marine diatoms. Protist. 2007;158:193-207.

59. Moschandreau KK, Papaefthimiou D, Katikou P, Kalopesa E, Panou A, Nikolaides G. Morphology, phylogeny and toxin analysis of Pseudo-nitzschia pseudodelicatissima (Bacillariophyceae) isolated from the Thermaikos Gulf, Greece. Phycologia. 2010;49:260-73.

60. Behnke A, Friedl T, Chepurnov VA, Mann DG. Reproductive compatibility and rDNA sequence analyses in the Sellaphora pupula species complex (Bacillariophyta). J Phycol. 2004;40:193-208.

61. Margalef R. Size of centric diatoms as an ecological indicator. Mitt Int Ver Limnol. 1969;17:202-10.

62. Zong Y. Implications of Paralia sulcata abundance in Scottish isolation basins. Diatom Res. 1997;12:125-50.

63. McQuoid MR, Nordberg K. The diatom Paralia sulcata as an environmental indicator species in coastal sediments. Estuar Coast Shelf Sci. 2003:56:339-54.

64. Hobson LA, McQuoid MR. Temporal variations among planktonic diatom assemblages in a turbulent environment of the southern Strait of Georgia British Columbia, Canada. Mar Ecol Prog Ser. 1997;150:263-74.

65. Liu D, Sun J, Zhang J, Liu G. Response of the diatom flora in Jiaozhou Bay, China to environmental changes during the last century. Mar Micropaleontol. 2008:66:279-90.

66. Ruiz GM, Smith G. Biological Study of Container Vessels at the Port of Oakland, Report submitted to the Port of Oakland. 2005. p. 1-155.

67. Lo VB, Levings CD, Chan KMA. Quantifying potential propagule pressure of aquatic invasive species from the commercial shipping industry in Canada. Mar Pollut Bull. 2012;64:295-302.

68. Long JL. Introduced Birds of the World: the Worldwide History, Distribution and Influence of Birds Introduced To New Environments. New York: Universe Book; 1981 
69. Veltman CJ, Nee S, Crawley MJ. Correlates of introduction success in exotic New Zealand birds. Amer Naturalist. 1996;147:542-57.

70. Fuller PL, Nico LG, Williams JD. Nonindigenous Fishes Introduced into Inland Waters of the United States. Bethesda: American Fisheries Society; 1999

71. Gebühr C, Wiltshire KH, Aberle N, van Beusekom JEE, Gerdts G. Influence of nutrients, temperature, light and salinity on the occurrence of Paralia sulcata at Helgoland Roads, North Sea. Aquat Biol. 2009;7:185-97.

72. Locarnini RA, Mishonov AV, Antonov Jl, Boyer TP, Garcia HE, Baranova OK, et al. Temperature. In: World Ocean Atlas 2009. Washington: U.S. Government Printing Office; 2010. p. 1-184. NOAA Atlas NESDIS 68, vol 1.

73. Antonov Jl, Seidov D, Boyer TP, Locarnini RA, Mishonov AV, Garcia HE, et al. Salinity. In: World Ocean Atlas 2009. Washington: U.S. Government Printing Office; 2010. p. 1-184. NOAA Atlas NESDIS 69, vol 2.

74. Garcia HE, Locarnini RA, Boyer TP, Antonov Jl. Nutrients (phosphate, nitrate, and silicate). In: World Ocean Atlas 2009. Washington: U.S. Government Printing Office; 2010. p. 1-398. NOAA Atlas NESDIS 71, vol 4

75. Garcia HE, Locarnini RA, Boyer TP, Antonov Jl, Baranova OK, Zweng MM, et al. Dissolved Oxygen, Apparent Oxygen Utilization, and Oxygen Saturation. In: World Ocean Atlas 2009. Washington: U.S. Government Printing Office; 2010. p. 1-344. NOAA Atlas NESDIS 70, vol 3.

76. Saltonstall K. Cryptic invasion by a non-native genotype of the common reed, Phragmites australis, into North America. Proc Natl Acad Sci U S A. 2002;99:2445-9.

77. Roman J. Diluting the founder effect: cryptic invasions expand a marine invader's range. Proc R Soc B. 2006;273:2453-9.

78. Lang I, Kaczmarska I. A protocol for a single-cell PCR of diatoms from fixed samples: method validation using Ditylum brightwellii (T. West) Grunow. Amer Naturalist. 2011;26:43-9.

79. Iwatani N, Murakami S, Suzuki Y. A sequencing protocol of some DNA regions in nuclear, chloroplastic and mitochondrial genomes with an individual colony of Thalassiosira nordenskioeldii Cleve (Bacillariophyceae) Polar Biosci. 2005;18:35-45.

80. White TJ, Bruns TD, Lee SB, Taylor JW. Amplification and Direct Sequencing of Fungal Ribosomal RNA Genes for Phylogenetics. In: Innis MA, Gelfand DH, Sninsky JJ, White TJ, editors. PCR Protocols: A Guide to Methods and Applications. London: Academic; 1990. p. 315-22.

81. Daugbjerg N, Andersen RA. A molecular phylogeny of the heterokont algae based on analyses of chloroplast-encoded rbcL sequence data. J Phycol. 1997:33:1031-41.

82. Hall TA. BioEdit: a user-friendly biological sequence alignment editor and analysis program for Windows 95/98/NT. Nucleic Acids Symp Ser. 1999;41:95-8.

83. Thompson JD, Higgins DG, Gibson TJ. CLUSTAL W: improving the sensitivity of progressive multiple alignment through sequence weighting, position-specific gap penalties and weight matrix choice. Nucleic Acids Res. 1994;22:4673-80

84. Tamura K, Peterson D, Peterson N, Stecher G, Nei M, Kumar S. MEGA5: Molecular evolutionary genetics analysis using maximum likelihood, evolutionary distance, and maximum parsimony methods. Mol Biol Evol. 2011;28:2731-9.

85. Posada D. jModelTest: phylogenetic model averaging. Mol Biol Evol. 2008;25:1253-6.

86. Ramírez-Flandes S, Ulloa O. Bosque: integrated phylogenetic analysis software. Bioinformatics. 2008;24:2539-41.

87. Ashworth MP, Ruck EC, Lobban CS, Romanovicz DK, Theriot EC. A revision of the genus Cyclophora and description of Astrosyne gen. nov. (Bacillariophyta), two genera with the pyrenoids contained within pseudosepta. Phycologia. 2012;51:684-99.

88. Zuker M. Mfold web server for nucleic acid folding and hybridization prediction. Nucleic Acids Res. 2003;31:3406-15.

89. Darty K, Denise A, Ponty Y. VARNA: Interactive drawing and editing of the RNA secondary structure. Bioinformatics. 2009;25:1974-5.

90. Mai JC, Coleman AW. The internal transcribed spacer 2 exhibits a common secondary structure in green algae and flowering plants. J Mol Evol. 1997:44:258-71.

91. Kaczmarska I, LeGresley MM, Martin JL, Ehrman J. Diversity of the diatom Pseudo-nitzschia Peragallo in the Quoddy Region of the Bay of Fundy, Canada. Harmful Algae. 2005;4:1-19.

92. MacGillivary ML, Ehrman JM. A readily available SEM substrate for a random orientation of diatom frustules. Diatom Res. 2011;26:321-3.
93. Gilmour JSL, Heslop-Harrison J. The deme terminology and the units of micro-evolutionary change. Genetica. 1954;27:147-61.

94. Suzuki R, Shimodaira H. Pvclust: an R package for assessing the uncertainty in hierarchical clustering. Bioinformatics. 2006;22:1540-2.

95. Shimodaira $\mathrm{H}$. An approximately unbiased test of phylogenetic tree selection. Syst Biol. 2002:51:492-508.

96. Shimodaira $\mathrm{H}$. Approximately unbiased tests of regions using multistep-multiscale bootstrap resampling. Ann Stat. 2004;32:2616-41.

\section{Submit your next manuscript to BioMed Central and take full advantage of:}

- Convenient online submission

- Thorough peer review

- No space constraints or color figure charges

- Immediate publication on acceptance

- Inclusion in PubMed, CAS, Scopus and Google Scholar

- Research which is freely available for redistribution 